\title{
OECD Ülkelerinde Toplam Faktör Verimliliği: Stokastik Sınır Yaklaşımı ile Bir Panel Veri Uygulaması*
}

Öz

Geliş Tarihi (Received): 05.02.2021 - Kabul Tarihi (Accepted): 07.06.2021

Sürdürülebilir büyümenin temel unsuru olan verimlilik, en yalın haliyle, emek, sermaye ve diğer üretim faktörlerinin ne düzeyde etkin ve etkili kullanıldığını ifade eden bir kavramdır. Bu kavram, ekonomik birimlerin girdilerini çıktıya dönüştürme kabiliyetinin bir göstergesidir. Kişi başı gelir düzeyi açısından ülkeler arasında büyük ve artan farklılıkların olduğu ve faktör birikimlerinin bu farklılıkları tam olarak açıklayamadığı dikkate alındığında, sürdürülebilir ekonomik büyüme için verimlilik artışı başat bir rol oynamaktadır. Çalışmada, toplam faktör verimliliği (TFV) büyümesi ve bileşenleri, 1970-2017 dönemine ilişkin olarak 28 OECD ülkesini içeren panel veri seti ve stokastik sınır analizi (SSA) yaklaşımıyla hesaplanmıştır. TFV'de, analiz döneminde panel geneli için yıllık ortama $\% 0,13$ oranında artış meydana geldiği tespit edilmiştir. 1970'li ve 1980'li yılların başı ile küresel krizin yaşandığ 2008 ve 2009 yıllarında yıllık ortalama verimlilik düşüşü yaşandığı, en derin düşüşün ise \%2,25 ile 2009 yılında ortaya çıktığı görülmektedir. TFV'deki büyümenin, teknik etkinlik ve ölçek etkinliğindeki iyileşmelerden çok, büyük ölçüde teknolojik ilerlemeye bağlı olduğu; yüksek kişi başı gelir düzeyine sahip ülkelerin de bu noktada hakim konumda olduğu çalışmada tespit edilen diğer bulgulardandır.

Anahtar Kelimeler: Stokastik Sınır Analizi, Toplam Faktör Verimliliği, Etkinlik, Verimlilik, Ekonomik Büyüme.

Jel Kodları: E23, E24, D24, C23.

Total Factor Productivity in OECD Countries: A Panel Data Application with Stochastic Frontier Approach

\begin{abstract}
Productivity, the fundamental element of sustainable growth, is the term that expresses the level of efficient and effective use of labor, capital and other production factors. This term is an indicator of the ability of economic units to transform their input into output. Considering large and increasing differences between countries in terms of per capita income and factor accumulations that cannot fully explain these differences, productivity growth plays a dominant role for sustainable economic growth. In this study, the total factor productivity (TFP) growth and its components were calculated with a panel data set that includes 28 OECD countries for the period 1970-2017 by using a stochastic frontier analysis. It was determined that the average annual increase of TFP was $0.13 \%$ during the analysis period. The annual average productivity declined in the years of the 1970s and the early 1980s. It also decreased in 2008 and 2009 when the global crisis was experienced. The deepest decline was seen in 2009 with $2.25 \%$. The growth in TFP is mainly dependent on technological progress rather than improvements in technical efficiency and scale efficiency. Another finding of the study is that countries with higher per capita income are also dominant in technological progress.
\end{abstract}

Keywords: Stochastic Frontier Analysis, Total Factor Productivity, Efficiency, Productivity, Economic Growth.

Jel Codes: E23, E24, D24, C23.

\footnotetext{
* Bu çalışma birinci yazarın ikinci yazar danışmanlığında hazırlamış olduğu doktora tezinden türetilmiştir.

***Doktorant, Ankara Hacı Bayram Veli Üniversitesi, Lisansüstü Eğitim Enstitüsü, İktisat Bölümü, nadidegulbay@gmail.com

**** Prof. Dr., Ankara Hacı Bayram Veli Üniversitesi, İ̈BF, İktisat Bölümü, fahriye.ozturk@ @bv.edu.tr
} 


\section{Giriş}

Geleneksel neoklasik büyüme modeli, üretim faktörlerinin etkin bir şekilde kullanıldığ1 ve üretim teknolojisinin tüm ülkeler için aynı olduğu varsayımına dayanmaktadır. $\mathrm{Bu}$ varsayımların terk edilmesi, etkinliğin ve üretim teknolojilerinin dolayısıyla verimliliğin ülkeler arasında farklılık gösterdiği anlamına gelmektedir. Bu durumda verimlilik farkları, ülkeler arası gelir farklılıklarının temel kaynaklarından biri olmaktadır.

Toplam faktör verimliliğine (TFV) ilişkin literatürün büyük kısmı bu kavramı açıklama probleminden çok ölçüm problemlerine odaklanmıştır. TFV, en yalın tanımı ile üretim sürecinde kullanılan girdiler sabitken çıktıda ortaya çıkan artışı ifade etmektedir. Girdi miktarı dışında kaynak tahsisindeki etkinlik, üretim teknolojisindeki iyileşmeler ve ortaya çıkan dışsallıklar bu değişken ile yakalanmaktadır. Bu kapsamda, teknik etkinlik, teknik ilerleme ve ölçek etkinliği TFV'nin temel bileşenleri olarak karşımıza çıkmaktadır. Teknik etkinlik değişimi, yakalama etkisi (catch-up) olarak da anılmakta olup mevcut teknolojilerin benimsemesini yani ülkelerin mevcut teknolojiye adapte olma performansını ifade etmektedir. $\mathrm{Bu}$ kavram matematiksel olarak da ülkenin teknoloji sınırından ne kadar uzakta olduğunu ve üretken kaynakların kullanımındaki başarı derecesini ifade eder. Teknik ilerlemedeki değişim ise daha üretken teknolojilerin benimsenmesi anlamını taşımakta olup matematiksel olarak da ülkenin üretim sınırında meydana gelen kaymaları göstermektedir.

Üretim faktörlerine ilişkin kısıtların ve azalan getirilerin söz konusu olduğu ekonomilerde, sermaye ve emek gibi üretim girdilerinin miktarını artırarak sürdürülebilir ekonomik büyümeyi sağlamak mümkün değildir. $\mathrm{Bu}$ durumda, ekonomik büyümeyi sürdürülebilir kılacak olan temel etken, girdilerin verimliliğinin artırılmasıdır. Ülkeler mevcut potansiyellerini etkin kullanamıyorlarsa potansiyellerini etkinleştirerek üretimlerini artırabileceklerdir. Potansiyel üretim sınırı dikkate alındığında ise teknolojik ilerleme temel seçenek olarak karşımıza çıkmaktadır.

$\mathrm{Bu}$ çerçevede çalışmada, ekonomilerin büyüme performansına ve bu büyümenin kaynaklarına ilişkin uluslararası düzeyde karşılaştırmalı bir bakış açısı sunulması amacıyla OECD ülkeleri kapsamında, TFV büyümesi hesaplanarak teknik etkinlik, teknik ilerleme ve ölçek etkinliği bileşenlerine ayrıştırılacaktır. Çalışmanın takip eden bölümünde, TFV'ye ilişkin farklı yaklaşımları içeren teorik çerçeve sunulacak; üçüncü bölümde, konuya ilişkin ampirik literatür özetlenecektir. Dördüncü ve beşinci bölümde sırasıyla, metodolojik çerçeve sunulacak ve uygulamaya temel teşkil eden veri seti tanıtılacaktır. Sonraki adımda, ampirik uygulama ve bulgular sunulacaktır. Çalışmanın son bölümü ise sonuç ve değerlendirmeleri içermektedir. 


\section{Teorik Arka Plan}

Sürdürülebilir büyümenin temel unsuru olan verimlilik, emek, sermaye ve diğer üretim faktörlerinin ne düzeyde etkin ve etkili kullanıldığını ifade eden bir kavramdır. Bu kavram, ekonomik birimlerin girdilerini çıktıya dönüştürme kabiliyetinin bir göstergesidir. Ekonomik birimler, üretim sürecinde, kaynakları tahsis etme ve kullanma konusunda ne kadar verimli olduklarına bağlı olarak aynı miktarda girdiyle daha fazla veya daha az çıktı üretebilmektedir. Kişi başı gelir düzeyi açısından ülkeler arasında büyük ve artan farklılıkların olduğu ve faktör birikimlerinin bu farklılıkları tam olarak açıklayamadığı dikkate alındığında sürdürülebilir ekonomik büyüme için verimliliğin iyileştirilmesi başat bir rol oynamaktadır (Easterly\& Levine, 2001; Hall \& Jones, 1999).

Verimlilik kavramı, iktisat yazınında ilk defa Georgius Agricola'nın (1530) çalışmasında kullanılmıştır (Kök \& Deliktaş, 2003). Söz konusu çalışmanın tarihi Merkantilist düşüncenin ilk evresine denk gelmektedir. Agricola, madenciliğin tarıma kıyasla daha verimli olduğunu vurgulamakta, ayrıca madencilik ve tarım alanında verimliliği artırmak için yapılması gereken teknik hususlara da değinmektedir (Hoover \& Hoover, 1912).

Merkantilizme tepki olarak Fransa'da ortaya çıkan Fizyokratların verimlilik kavramına bakışını, Quesnay (1758)'in "Ekonomik Tablo"” çalışmasında yer alan akım şeması yansıtmaktadır. Bu düşünceye göre, zenginliğin esas kaynağı artı değer yaratan tek sektör olan tarım sektörü, üretken tek sınıf da toprağı işleyen sınıftır (Sweezy, 1970). Bu düşünce ile verimlilik kavramı artık netleşmeye başlamış olup verimli emek-verimsiz emek ayrımı yapılmaya başlamıştır.

Klasik okulun temsilcilerinden Adam Smith'e (1723-1790) göre ülkenin zenginliğini artırmak üretim faktörlerinin verimliliğini artırmak ile mümkündür. İşbölümü, emeğin verimliliğinin artmasına neden olan en önemli faktör olarak tanımlanmaktadır. Smith sektörleri işbölümünü mümkün kılmalarına göre gruplandırmıştır. Ona göre tarım en verimli işkoludur. Sanayi ise tarımdan daha fazla işbölümü imkanı sunmakta olup verimlilik artışı açısından tarımdan daha ileridedir (Smith, 1976).

Klasik okulun bir diğer temsilcisi Ricardo’ya (1772-1823) göre bir ülkenin zenginliği sanayileşmesine bağlıdır. Tarım alanında yeni teknikler ile verimlilik artırılabilse de bu sektörün azalan verimlerle çalışan yapısına bağlı olarak teknolojik gelişmelerle üretkenliğin artırılabileceği esas işkolu sanayidir. Ricardo, teknolojik gelişmeyle birlikte üretimin herhangi

\footnotetext{
${ }^{1}$ Tableau Economique
} 
bir branşında makine kullanımının işgücü tasarrufu etkisine sahip olduğunu vurgulamaktadır (Ricardo, 1951).

Marx’a (1818-1883) göre, büyümenin kaynağı olan sermaye birikimi kapitalistlerin kâr oranlarının bir fonksiyonudur. Kapitalistlerin kâr oranlarını belirleyen temel faktör artık değer olduğundan büyümenin arkasındaki itici güç de artık değerdir. Artık değer ise emeğin verimliliğinin artması ile yani işçiyi daha fazla değişmez sermaye ile donatmakla mümkündür. Ancak, belli süre sonra emeğin verimliliğini artırmak artık mümkün olmamaktadır. Bu da kâr oranlarının düşmesine neden olacaktır. Ancak Marx, kâr oranlarının düşmesi sürecini tersine çevirecek mekanizmaların da kapitalist sistemde olduğunu belirtmektedir (Marx, 2018).

Schumpeter (1883-1950), girişimci kavramını ekonomik analizin merkezine taşımakta olup girişimcinin teknolojik bir yenilikçi olarak rolünü vurgulamaktadır. Schumpeter'e göre, ekonomik büyümenin kaynağı yeniliklerdir. Bu yenilikler, yeni bir ürünün bulunması veya eski üründe niteliksel bir yenilik; üretim yönteminde yenilik; yeni piyasaların geliştirilmesi ve yeni ticaret olanaklarının bulunması; yeni hammadde kaynaklarının bulunması; organizasyon yapılarında yenilik sağlanması, şeklinde ortaya çıkabilmektedir (Schumpeter, 1934). Firmalar, yaratıcı yıkım sürecinde yok olmamak için yeni fikirler geliştirmeye ve verimliliklerini artırmaya teşvik edilmiş olmaktadır (Schumpeter, 1950).

Keynes (1883-1946) Genel Teoride (1936), piyasa mekanizmasının tam istihdamı kendiliğinden sağlamasının mümkün olmadığını belirterek kısa dönemli statik bir analiz yapmıştır. $\mathrm{Bu}$ yaklaşımda ekonominin durgunluktan ne şekilde çıkacağı konusuna odaklanılmıştır. Verimlilik konusuna ilişkin olarak ise Keynes, istihdam ve talebin yüksek olduğu durumlarda bu sorununun çözülmüş olabileceğini belirtmektedir (Kök, 1991).

Post Keynesyen Okulun temsilcilerinden Harrod ${ }^{2}$ ve Domar, Keynes'in analizini uzun vadeye genişleterek dinamik ve büyüyen bir ekonominin hangi koşullar altında tam istihdamı gerçekleştirebileceği ve bunu devam ettirebileceği sorusuna odaklanmaktadır. Harrod-Domar modeline göre yatırım hem Keynesyen çarpan analizindeki gibi gelir üretmekte hem de ekonominin üretken kapasitesini artırmaktadır. İlk etki kısa vadeli bir yapıya sahip olup talep tarafında görünürken, ikinci etki uzun vadeli bir yapıda olup arz tarafında ortaya çıkmaktadır (Hagemann, 2009).

Neoklasik İktisat Okulunda büyüme teorisinin kökenleri Solow (1956, 1957) çalışmalarına dayanmaktadır. Solow’un $(1956)^{3}$ standart neoklasik iktisadi büyüme modelinde,

\footnotetext{
${ }^{2}$ Harrod (1939), yatırımın sermaye birikimi etkisini de analize dahil etmiş, piyasa mekanizmasının büyüyen dinamik bir ekonomide kendiliğinden tam istihdamı sağlayıp sağlamadığını araştırmıştır.

${ }^{3}$ Tinbergen (1942), nüfus artışı, teknik ilerleme ve sermaye oluşumunun etkisi altında ekonominin uzun vadeli gelişimini araştırmış olup model Solow modelinin en gelişmiş öncüsüdür (Hagemann, 2009).
} 
tasarruf yatırım düzeyinin büyümeyi sadece geçiş döneminde etkilediğini belirtilerek sermaye birikiminin büyüme üzerindeki etkisi minimize edilmektedir. Bu modele göre, uzun dönemde büyümenin kaynağ teknolojik değişme olup üretim fonksiyonunda teknoloji dişsal bir faktör olarak ele alınmakta ve kişi başına çıktı, sabit teknolojik gelişme oranında büyümektedir (Jones, 2001). Uzun vadeli ekonomik büyümeyi sürdürmek için, teknolojide sürekli gelişmeler sağlanarak, zamanla ekonomik büyümenin durmasına neden olacak azalan getirilerin etkileri elimine edilebilmektedir (Aguiar, Costa \& Silva, 2017). Solow (1957), gelir artışının kaynaklarını açıklamak için büyüme muhasebesi çerçevesini oluşturmuştur. Gelir artışının, işgücü ve sermaye ile açıklanamayan bakiye kısmı bu yaklaşımda "Solow Artığı" olarak ifade edilen bir artık terim ile ölçülmektedir. $\mathrm{Bu}$ artı $\mathrm{k}^{4}$ verimliliğe denk gelmekte olup geliri etkileyen işgücü ve sermaye dışındaki faktörleri barındırmaktadır. Neoklasik modelde, bu artık aynı zamanda dişsal olarak kabul edilen teknoloji parametresi olarak tanımlanmakta olup nasıl ortaya çıktığı açıklanmamaktadır. Bu haliyle teknoloji, tesadüfi ilerlemelere bağlı bir fenomen olarak tanımlanmıştır. Neoklasik modelde, sermayenin marjinal verimliliğinin azalması sebebiyle teknolojik ilerleme ortaya çıkmazsa büyüme durağan duruma girmekte, durağan durum kişi başı gelir değeri ise tasarruf oranı ve nüfus artış oranı tarafından belirlenmektedir. Teknolojik gelişme sermayenin verimliliğinin azalmasını engellemekte, kişi başı durağan durum gelir büyüme oranı da dışsal olan teknolojik ilerleme hızı tarafından belirlenmektedir (Mankiw, Phelps \& Romer, 1995).

Neoklasik yaklaşımın temel kavramı olan Solow kalıntısının içeriğini incelemeye yönelik girişimler, "İçsel Büyüme Teorileri" adı verilen yeni bir dizi teoriye yol açmıştır. Bu modellerde uzun vadeli gelir artışının ana itici gücü olan toplam faktör verimliliği büyümesine ve kişi başına gelirdeki ülkeler arası farklılıklara artan bir odaklanma söz konusudur (Aguiar, Costa \& Silva, 2017). İçsel büyüme ile ilgili literatür, dışsallıklar yaratan fiziki sermayeye, beşeri sermayeye ve ARGE'ye dayanmaktadır. Ayrıca bilgi de bir sermaye türü olarak kabul edilmektedir ${ }^{5}$. Bu varsayıma bağlı olarak sermayenin azalan getiri sergileme olasılığ düşmektedir. Üretim ve yatırım sürecinde ortaya çıkan bilgi ekonomide verimlilik artışı sağlamaktadır. Bilginin, pozitif dışsallıklara ve artan getiriye sahip olmasına bağlı olarak durağan duruma girilmeyen sürekli bir büyüme süreci yaşanabilecektir ${ }^{6}$ (Mankiw, Phelps \& Romer, 1995).

\footnotetext{
${ }^{4}$ Abramovitz (1956), bu artığı cehaletin ölçüsü “measure of ignorance” olarak ifade etmektedir.

${ }^{5}$ Mankiw vd. (1995), bilginin, bilgi üretmek için kullanıldığını bu nedenle diğer sermaye biçimleriyle karşılaştırıldığında, bilgi üretiminin azalan getiri sergileme olasılığının daha düşük olduğunu hatta artan getiri bile gösterebileceğini belirtmektedir (Mankiw, Phelps, \& Romer, 1995).

${ }^{6}$ Mankiw vd. (1995)'ne göre bilgi, toplumun ders kitaplarının kalitesi, beşeri sermaye, onları okumak için harcanan zamandır.
} 
Yeni klasik reel konjonktür teorisine göre ekonomideki istikrarsızlıkların temel nedeni reel şoklar olup bu istikrarsızlıklar stokastik (öngörülemez/rastgele) sapmalar şeklindedir. Ekonominin faktör donanımı ve teknoloji seviyesi gibi reel faktörler, üretim ve istihdam düzeyindeki dalgalanmalara neden olmaktadır. Teknolojik ilerleme pozitif bir şoka neden olurken yeni teknolojilere uyum sağlayamayan işkollarına bağlı olarak negatif şoklar ortaya çıkmaktadır. Pozitif teknolojik şok durumunda verimlilik ve reel ücret seviyesi yükselmekte, bu durumda işçiler, çalışma-boş zaman tercihlerini çalışma lehine değiştirmektedir. Böylece üretim ve istihdam artmaktadır (Bocutoğlu, 2012).

Klasik, Neoklasik, Keynesyen ve Schumpeteryen iktisatçılar, ekonomik büyümeyi teşvik etmede verimliliğin anahtar rol oynadığını kabul etmektedirler (Archibugi \& Michie, 1998). Sürdürülebilir büyümenin temel unsuru olan verimliliğe ve büyümeye elverişli bir ekonomik yapının çerçevesinin çizilmesine yönelik olarak giderek büyüyen teorik ve ampirik bir literatür bulunmaktadir.

\section{Literatür Özeti}

Temel olarak, literatürde toplam faktör verimliliğini hesaplayan yöntemler sınır (frontier) ve sınır-olmayan (non-frontier) yaklaşım olmak üzere iki ana başlık altında toplanabilmektedir. Sınır yaklaşımı stokastik sınır, bayesian yaklaşım ve veri zarflama alt başlıklarını; sınırolmayan yaklaşım ise geleneksel büyüme muhasebesi tekniğini içermektedir. Çalışmanın bu bölümünde ampirik bir bakış açısıyla toplam faktör verimliliğini ve bileşenlerini analiz eden çalışmalara değinilecektir.

Fare vd. (1994) çalışmasında, 1979-1988 dönemine ilişkin olarak, OECD ülkelerinde ortalama olarak TFV değişiminin yılda \%0,7 olduğu; teknolojik ilerlemenin tüm ülkelerdeki TFV değişikliğini açıkladığı ve yıllık ortalama \%0,85'lik bir değişim gösterdiği; teknik etkinliğin ise zamanla azaldığı belirtilmektedir.

Golany ve Thore (1997a) çalışmasında, ölçeğe göre artan getiriye sahip ülkeler için, GSYH ve sosyal performansın uzun vadeli büyümesinin devam ettiği; ölçeğe göre azalan getiri sergileyen ülkelerde ise GSYH ve sosyal performansta bir yavaşlamanın olduğu belirtilmektedir. Ölçeğe göre azalan getiriye sahip ülkelerdeki eğitim, sağlık ve sosyal politikalar, ülkeleri harcamaların marjinal getirilerinin düştüğü noktaya doğru itmektedir. Bu kategoriye ait ülkeler genellikle gelişmiş ülkeleri içermekte olup ölçeğe göre artan getiri durumundaki ülkeler ise gelişmekte olan genç ülkeler olarak nitelendirilmektedir.

Rao ve Coelli (1998) çalışmasında, 1965-1990 dönemi için Latin Amerika, Kuzey Afrika ve Orta Doğu için negatif yıllık TFV büyümesi tespit edilmişken, Asya, yıllık ortalama \% 0,99 ile en yüksek TFV büyümesine sahip bölge olarak bulgulanmıştır. OECD ülkelerinden 
Danimarka, İtalya ve Hollanda'da teknolojik gerileme tespit edilmiştir. Kore de teknolojik gerilemenin görüldüğü ülkeler arasında yer almıştır. Teknik etkinlikteki değişimin, olumsuz teknolojik değişim yaşayan ülkeler için daha yüksek olduğu çalışmada elde edilen diğer bir sonuçtur.

Koop, Osıewalskı ve Steel (2000), 1980-1990 dönemi için 20 ülkenin etkinlik ve verimliliklerindeki değişimlerini analiz etmişlerdir. Çalışmada ortalama etkinlik 0,880 olarak tespit edilmiş olup Hollanda etkinliği en yüksek ülke $(0,975)$, Polonya ise etkinliği en düşük $(0,450)$ ülkedir. Çalışma kapsamında yıllık ortalama \%0,58 teknik ilerleme gerçekleştiği tespit edilmiştir. En yüksek teknik ilerlemeye sahip olan ülke Almanya olarak tespit edilmiştir.

Arcelus ve Arocena (2000) çalışmasında, 1970-1990 dönemine ilişkin olarak 14 OECD ülkesi için analiz dönemi boyunca ortalama $0,835^{\prime}$ 'lik ortalama etkinlik tespit edilmiştir. Analiz dönemi içinde ortalama etkinliği en yüksek ülke Belçika $(0,987)$, en düşük ülke ise İsveç olarak hesaplanmıştır.

Forstner ve Isaksson (2002) çalışmasında OECD ülkeleri için TFV büyümesinin inovasyona dayandığı; "Asya Kaplanı" ekonomilerinin büyümesinin önemli ölçüde TFV büyümesi kaynaklı olduğu ve bunun ise esas olarak teknik etkinlikteki iyileşmeden kaynaklandığı bulgulanmıştır. OECD ülkelerinin incelenen dönemde y1llık ortalama \%0,1 etkinlik değişimi; \%0,8 teknik ilerleme ve \%0,9 TFV büyümesi sergilediği hesaplanmıştır. Asya Kaplanı ekonomilerinin ise yıllık ortalama \%3,1 etkinlik değişimi; \%0,1 teknik ilerleme ve \% 3,1 TFV büyümesi sergilediği hesaplanmıştır.

Kim, Park ve Park (2010) çalışmasında, dünya verimlilik artışının hızlı büyüyen yeni gelişen ekonomiler tarafından yönetildiği; çoğu gelişmiş ülkenin verimlilik büyümesinde bir düşüş yaşadığı; teknik etkinlik açısından gelişmekte olan ekonomilerin gelişmiş ülkelerin gerisinde kaldığ çalışmada altı çizilen sonuçlardır.

Bos vd. (2010), büyümenin, gelişmiş ekonomilerde faktör birikimine ve sermayeye; yükselen ekonomilerde teknik değişime; gelişmekte olan ülkelerde ise hem teknik değişime hem de emek birikimine bağlı olduğu sonucuna ulaşmaktadır. Bir diğer bulgu ise gelişmekte olan ülkelerin, mevcut teknolojileri kullanma becerilerinin geliştirmesinin tek başına yeni teknolojilerin yayılmasını teşvik etmekten daha etkili olabileceği şeklindedir.

Pires ve Garcia (2012) çalışmasında, Japonya $(\% 2,42)$, Avusturya $(\% 1,77)$, Fransa $(\% 1,75)$, Norveç $(\% 1,53)$, İsviçre $(\% 1,51)$ ve ABD $(\% 1,49)$ verimlilik değişimi açısından üst sıralarda yer alan ülkeler olarak hesaplanmıştır. Yunanistan ve Türkiye, negatif verimlilik artışına sahip OECD üyesi ülkelerdir. Teknik ilerlemenin verimlilik artışı üzerinde en büyük etkiyi gösterdiği ülkeler sırayla Japonya, ABD, Fransa, İsviçre, İtalya, İngiltere, Hollanda ve 
Avustralya olarak tespit edilmiştir. Bu ülkelerde teknik ilerlemenin katkıları yılda ortalama $\% 0,56$ ile \%0,30 arasında değişmektedir.

Aguiar, Costa ve Silva (2017), çalışmasında OECD ülkeleri için ortalama etkinlik 0,68, ölçeğe göre getiri 0,82, yıllık ortalama TFV değişimi \%0,29, yıllık ortalama teknik ilerleme \%7,07, yıllık ortalama teknik etkinlik değişimi \%8,16, yıllık ortalama ölçek etkisi değişimi \%0,8 olarak tahmin edilmiştir.

Heshmati ve Rashidghalam (2020) çalışmasında, teknik değişimin TFV büyümesinin en önemli bileşeni olduğu bulgulanmıştır. Ayrıca çalışmada, teknik değişim ve TFV büyümesi tüm ülke gelir grupları ve yıllarında negatif olarak bulgulanmıştır.

Fuente-Mella vd. (2020), 34 OECD üye ülkesi için 2003-2012 dönemine ilişkin olarak yaptığı çalışmada, Lüksemburg ve ABD gibi daha yüksek ekonomik büyüme düzeyine sahip ülkelerin daha yüksek; Şili ve Meksika gibi daha alt sıralarda ekonomik büyüme düzeyine sahip ülkelerin ise daha düşük verimliliğe sahip olduğunu tespit etmişlerdir.

Hou vd. (2020), 16 ülke için yıllık ortalama TFV büyümesini \% 1,4 olarak tahmin etmiştir. Bunun \%0,006'sı etkinlik değişimi; \%1,4'ü teknolojik ilerleme; \%-0,026's ölçek etkisinden kaynaklanmaktadır. Analiz döneminde ve incelenen ülkeler kapsamında TFV'deki büyümenin, teknik etkinlik ve ölçek etkinliğindeki iyileşmelerden çok, büyük ölçüde teknolojik ilerlemeye bağlı olduğu hesaplanmıştır. 


\section{Metodoloji}

TFV için bir ölçü geliştirmek temel uğraş alanlarından biri olarak karşımıza çıkmaktadır. Literatürde TFV'yi hesaplayan yöntemler sınır (frontier ${ }^{7}$ ) ve sınır-olmayan (non-frontier) yaklaşım olmak üzere iki ana başlık altında toplanabilmektedir. Sınır-olmayan yaklaşımda ekonomik birimlerin teknik olarak etkin olduğu varsayımsal olarak kabul edilmekte olup TFV büyüme ölçüsü olarak teknolojik ilerleme dikkate alınmaktadır. Burada teknik etkinsizlik dikkate alınmadığı için üstü kapalı olarak uzun dönem dengesinde olunduğu varsayılmaktadır. Sınır-olmayan yaklaşım ile sınır yaklaşım arasındaki temel fark da teknik etkinliğe bakış açısından kaynaklanmaktadır. Sınır yaklaşımında TFV büyümesi, üretim fonksiyonunu yukarı kaydıran bir teknolojik ilerleme ile üretim sınırına doğru hareketi sağlayan teknik etkinlikten kaynaklanmaktadır. TFV büyümesi üretim sınırı tahmininde teknik ilerleme, teknik etkinlik kazançları ve ölçek etkinliği olmak üzere; maliyet, gelir ve kâr sınırı tahmininde ise teknik ilerleme, teknik etkinlik, tahsis etkinliği ve ölçek etkinliği olmak üzere bileşenlerine ayrılmaktadır (Mahadevan, 2004). Üretim etkinliği, herhangi bir fiyat bilgisine başvurmaksızın yalnızca fiziksel bir kavram olarak karşımıza çıkmaktadır. Maliyet, gelir ve kâr etkinliği ise hem fiyat bilgisi hem de üreticiye uygun davranışsal bir amaç yükleyen ölçüm konseptini içermektedir (Kumbhakar \& Lovell, 2000).

Çalışma kapsamında sınır analizi ana başlı̆̆ı altında yer almakta olan SSA Greene (2005) spesifikasyonu kullanılarak etkinsizlik modellenecektir. Bu yöntemin alternatif modellere göre temelde iki kazanımı bulunmaktadır. İlk olarak, etkinsizlik terimi için farklı istatistiksel dağılımlara izin vermesi, ikinci olarak da birime özgü heterojenliğin teknik etkinsizlikten ayrıştırılmasına imkân sağlamasıdır. Panel veri modelleri içerisinde etkinsizliği belirlemeye yönelik olarak birçok spesifikasyon bulunmakla birlikte, Kumbhakar (1990), Kumbhakar ve Heshmati (1995), Battese ve Coelli (1988, 1992, 1995), Kumbhakar ve Wang (2005), Wang ve Ho (2010) ile Kumbhakar, Lien ve Hardaker (2014) ampirik çalışmalarda en sık kullanılan diğer alternatif yöntemlerdir.

Greene $(2005 a, b)^{8}$, Gerçek Sabit Etkiler (True Fixed Effects-TFE) ve Gerçek Rastgele Etkiler (True Random Effects-TRE) olarak adlandırılan iki model sunmaktadır (Kumbhakar,

\footnotetext{
${ }^{7}$ Frontier yaklaşımın temelini oluşturan frontier kavramı en iyi elde edilebilir konum anlamına gelmektedir.

${ }^{8}$ Greene 2005 'e kadar zamanla değişen stokastik sınır modellerin ortak özelliği a'nın üretken birimler arasında aynı olması ve böylece üretim süreciyle ilgisi olmayan ancak çıktıyı etkileyen zamanla değişmeyen gözlemlenemeyen faktörlerin varlığında sapmalı tahminlere yol açmasıdır. Bu nedenle, bu faktörlerin etkisi, sonuçların sapmalı olması nedeniyle etkinsizlik terimi tarafından yakalanabilmektedir. Greene (2005) bu soruna, birime özgü $\alpha$ ile zamanla değişen (time varying) stokastik sınır normal-yarı normal modeli aracılığıyla yaklaşmıştır. Önceki modellerle karşılaştırıldığında, bu yaklaşım, birime özgü zamanla değişmeyen gözlemlenmemiş heterojenlikten, zamana bağlı etkinsizliğin çözülmesine izin vermektedir. Bu nedenle Greene
} 
Lien \& Hardaker, 2014). Bu modeller ile birime özgü etkinsizliğin zamanla değiştiği ve etkinsizlikle ilgili olmayan birim hetorejenliğinin $u_{i t}$ tahmininden ayrıştırıldığı yeni bir stokastik sınır formüle edilmektedir. TFE ve TRE modeli arasındaki temel fark sabit terim 'den kaynaklanmaktadır. $\alpha_{i}$ etkinsizliğin bir parçası olmayan sabit parametreler gibi hareket ediyorsa TFE modeli; rastgele bir değişken olarak hareket ediyorsa TRE modeli söz konusudur. Greene (2005b) TFE modeli formülasyonu 1 nolu eşitlikte yer almaktadır.

$$
y_{i t}=\alpha_{i}+\beta^{\prime} x_{i t}+v_{i t}+u_{i t} \quad i=1, \ldots, N ; t=1, \ldots, T
$$

1 nolu eşitlikte yer almakta olan $\alpha_{i}$ gruba özel sabittir. Bu modelde $\beta_{i}$ lerin tahmininde maksimum olabilirlik tahmin edicisi kullanılmaktadır. $y_{i t}, \mathrm{t}$ zamanında $\mathrm{i}$ firmasının performansını (çıktısını, kârını, maliyetini); $x_{i t}$ girdi veya girdi fiyat vektörünü göstermektedir. Etkinsizlik terimi $u_{i t}$ 'nin işareti sınırın üretim, kâr veya maliyet sınırı olup olmamasına göre değişmektedir. Söz konusu terimin işareti üretim ve kâr sınırı hesaplandığında “-”; maliyet sınırı hesaplandığında ise "+" olmaktadır. Rastgele değişken olan $v_{i t}$ (klasik ölçüm hatası, white noise) negatif veya pozitif olabilir. SSA'da $u_{i t}$ ve $v_{i t}$ 'nin toplamı birleşik hata terimini oluşturmaktadır.

Greene (2005a,b), tarafından önerilen diğer alternatif spesifikasyon olan TRE modelinde ise $\alpha_{i}$ 'nin her birim için aynı olduğu varsayılmaktadır. TRE model spesifikasyonu 2 nolu eşitlikte gösterilmektedir (Greene, $2005 \mathrm{a}, \mathrm{b}$ ).

$$
y_{i t}=\alpha+\beta^{\prime} x_{i t}+w_{i}+v_{i t} \pm u_{i t} \quad i=1, \ldots ., N ; t=1, \ldots, T
$$

TRE modeli, rastgele (firmalar arası) sabit bir terimi olan stokastik bir sınır modelidir. Model firmaya özgü etkinsizliğin zamanla değiştiği ve etkinsizlikle ilgili olmayan firma hetorejenliğinin $u_{i t}$ tahmininden ayrıştırıldığı bir yapı içerirken stokastik sınır modelinin temel özelliklerini de korumaktadır. $u_{i t}$ ve $v_{i t}$ simetrik ve tek taraflı bileşenlerdir. Bu formülasyon ile 1 nolu eşitlik ile verilen TFE modeli arasındaki temel fark, $w_{i}$ bileşeninden kaynaklanmaktadır. $w_{i}$ rastgele firma spesifik etki olup bileşeninin modeldeki diğer tüm terimlerle ilişkisiz olduğu varsayılmaktadır. Bu bileşen zamanla değişmeyen, firmaya özgü rastgele bir terim olarak firmalar arası heterojenliği yakalamak için kullanılmaktadır. (Belotti, Daidone, Ilardi, \& Atella, 2013) 
Model $v_{i t}$ ve $u_{i t}$ terimlerinin farklı dağılımsal özelliklerine göre parametre tahminine yönelik 3 temel yaklaşım sunmaktadır'. $v_{i t}{ }^{\prime}$ nin bağımsız bir şekilde $v_{i t} \sim N\left[0, \sigma_{v}^{2}\right]$ dağıldığ varsayılmaktadır. $\mathrm{Bu}$ varsayım ile modelde etkinsizlik terimi $u_{i t}$ için 3 farklı dağılım varsayılabilmektedir: Üstel (Exponential) dağılımda, $u_{i t}, \sigma_{u}^{2}$ varyans ile bağımsız ve üstel dağılmaktadır; yarı normal (half-normal) dağılımda, $u_{i t}$, bağımsız ve yarı normal olarak $N^{+}\left[0, \sigma_{u}^{2}\right]$ dağılmaktadır; kesikli normal (truncated-normal) dağılımda $u_{i t}$, bağımsız olarak $\mu$ kesim noktasında $N^{+}\left[\mu, \sigma_{u}^{2}\right]$ dağılmaktadır. Bu dağılımlar heteroskedastik hata bileşenli modellere de uymaktadir.

Çalışma kapsamında, nihai olarak teknik etkinsizlik, Jondrow vd. (1982) çalışmasını takiben $u_{i t}$ 'nin dağılımına bağlı ve koşullu ortalama şeklinde $\hat{u_{i t}}=E\left(u_{i t} \mid \varepsilon_{i t}\right)$ tahmin edilecektir. Toplam faktör verimliliği büyümesinin elde edilmesinde ve bileşenlerine ayrıştırılmasında ise Kumbhakar, Wang ve Horncastle (2015) takip edilecektir.

Panel veri ve çıtı odaklı teknik etkinsizlik dikkate alındığında, tek çıktılı üretim fonksiyonu 3 nolu eşitlikte sunulmaktadır.

$$
y_{i t}=f\left(x_{i t}, t ; \beta\right) \exp \left(-u_{i t}\right) \quad i=1, \ldots . ., N ; t=1, \ldots . ., T
$$

$y_{i t}, \mathrm{t}$ zamanı için i ekonomik biriminin çıktısını; $x_{i t}$ girdi vektörünü; t teknoloji değişiminin hesaplanması için vekil (proxy) niteliği taşıyan zaman trend değişkenini; $\beta$ tahmin edilen teknoloji parametre vektörünü; $u_{i t} \geq 0$ olmak üzere çıktı odaklı teknik etkinsizliği göstermektedir. TFV değişimi ise 4-12 nolu eşitliklerle tanımlanmaktadır. $w_{n}, x_{n}$ girdisine ait fiyatı; $S_{n}, x_{n}$ girdisinin toplam harcama içindeki payını; $C$ toplam harcamayı göstermektedir. Değişkenlerin üzerindeki “•” işareti bu değişkenlere ilişkin değişim oranını ifade etmektedir (Kumbhakar, Wang \& Horncastle, 2015).

$$
\begin{gathered}
\dot{T F P}=\dot{y}-\sum_{n} S_{n} \dot{x}_{n} \\
\dot{y}=\frac{1}{y} \frac{d y}{d t}=\frac{d \ln y}{d t} \\
C=\sum_{n} w_{n} x_{n} \\
S_{n}=w_{n} x_{n} / C \quad w=w_{1}, w_{2}, w_{3}, \ldots w_{N}>0
\end{gathered}
$$

\footnotetext{
${ }^{9}$ Greene (2005a) genel olarak, sonuçlar üzerindeki en büyük etkinin nadiren dağılım varsayımları olduğunu ve dağılımsal varsayımların tahminlerde sadece marjinal değişiklikler meydana getirdiğini; sonuçların birincil belirleyicisinin, modelin altında yatan formülasyon ve teorik temellerin olduğunu belirtmektedir.
} 
TC teknik değişim; TEC teknik etkinlikteki değişim; son bileşen ölçek etkinliği bileşeni; $\varepsilon_{n}$ her bir girdiye göre çıktı esnekliği olmak üzere;

$$
\begin{gathered}
\dot{T F P}=T C+T E C+\sum_{n}\left[\varepsilon_{n}-S_{n}\right] \dot{x}_{n} \\
\dot{T F P}=T C+T E C+(\varepsilon-1) \sum_{n}\left[\frac{\varepsilon_{n}}{\varepsilon}\right] \cdot \dot{x}_{n}+\sum_{n}\left[\frac{\varepsilon_{n}}{\varepsilon}-S_{n}\right] \dot{x}_{n} \\
T C=\frac{\partial \ln y_{i t}}{\partial t} \\
T E C=-\frac{\partial u}{\partial t} \\
\varepsilon_{n}=\varepsilon_{n}(x, t ; \beta)=\frac{x_{n} f_{n}(x, t ; \beta)}{f(x, t ; \beta)}
\end{gathered}
$$

TEC üreticinin üretim sınırına yaklaşıp uzaklaşma oranı olarak yorumlanabilmekte olup bu değişken zamanla artabilir, azalabilir veya değişmeyebilir. 9 nolu eşitlikte yer alan $(\varepsilon-1) \sum_{n}\left[\frac{\varepsilon_{n}}{\varepsilon}\right] \dot{x}_{n}$ bileşeni ölçek bileşenini ${ }^{10} ; \sum_{n}\left[\frac{\varepsilon_{n}}{\varepsilon}-S_{n}\right] \dot{x}_{n}$ bileşeni ise tahsis etkinsizliği bileşenini vermektedir. Eğer üretim teknolojisi ve teknik etkinlik zamanla değişmez ise bu bileşenler toplam faktör verimliliğindeki değişime katkı sağlamaz. Ölçek ekonomilerinin katkısı ise üretim teknolojisine ve veriye bağlıdır. Ölçeğe göre sabit getiri koşullarında girdi büyümesi veya daralması verimlilik değişimine katkıda bulunmaz. Ölçek esnekliği $\varepsilon=\varepsilon(x, t ; \beta)>1 \quad$ ve $\sum_{n}\left[\frac{\varepsilon_{n}}{\varepsilon}\right] \dot{x}_{n}>0$ olursa ölçek, verimlilik değişimine pozitif katk1 sağlayacaktır. Tahsis etkinsizliği ise girdilerin normalleştirilmiş çıktı esnekliklerinin harcama paylarından veya girdi fiyatlarının marjinal ürün değerinden sapmalarının etkisini göstermektedir. Eğer fiyat bilgisi mevut değilse tahsis etkinsizliğinin olup olmadığına bakılmaksızın tahsis etkinsizliği bileşeni ampirik olarak hesaplanamayacaktır. $\mathrm{Bu}$ durumda dolaylı olarak $S_{n}=\frac{\varepsilon_{n}}{\varepsilon}$ olacak TFV 12 nolu eşitlikte ifade edildiği şsekilde hesaplanacaktır (Kumbhakar \& Lovell, 2000).

\footnotetext{
${ }^{10}$ Ölçek esnekliği $\varepsilon=\varepsilon(x, t ; \beta)=\sum_{n} \varepsilon_{n}(x, t ; \beta), 1$ eşit, 1'den küçük veya büyük olabilmekte olup üretim sınırını karakterize eden ölçeğe ilişkin temel bir getiri ölçütü sağlamaktadır.
} 


$$
\dot{T F P}=T C+T E C+(\varepsilon-1) \sum_{n}\left[\frac{\varepsilon_{n}}{\varepsilon}\right] \dot{x}_{n}
$$

\section{Veri Seti ve Model}

Model, girdi ve çıktıların seçiminde bu alanda yapılmış daha önceki araştırma çizgileri de takip edilerek kurgulanmıştır. Analizler OECD ülkeleri kapsamında yapılmış olup, reel GDP, işgücü, sermaye, beşeri sermaye, ortalama yıllık çalışma saati temel değişkenler olarak kullanılmıştır. Bu değişkenlere ilişkin veri kaynakları Tablo 1'de sunulmaktadır.

Tablo 1. Veri Kaynakları

\begin{tabular}{|c|c|c|c|c|}
\hline Değişken & Simge & Veri Kaynă̆ı & Dönemi & Ölçümü Birimi \\
\hline Reel GDP & $\mathbf{Y}$ & Penn World Table Version 9.1 & $1970-2017$ & $\begin{array}{l}\text { Düzey değeri doğal } \\
\text { logaritma }\end{array}$ \\
\hline Sermaye Stoku & $\mathbf{K}$ & Penn World Table Version 9.1 & $1970-2017$ & $\begin{array}{l}\text { Düzey değeri doğal } \\
\text { logaritma }\end{array}$ \\
\hline İstihdam & $\mathbf{L}$ & Penn World Table Version 9.1 & $1970-2017$ & Doğal logaritma \\
\hline $\begin{array}{l}\text { Beşeri Sermaye } \\
\text { Endeksi }\end{array}$ & $\mathbf{H}$ & Penn World Table Version 9.1 & $1970-2017$ & $\begin{array}{l}\text { Endeks değeri doğal } \\
\text { logaritma }\end{array}$ \\
\hline $\begin{array}{l}\text { Ortalama Yıllık } \\
\text { Çalışma Saati }\end{array}$ & AVH & Penn World Table Version 9.1 & $1970-2017$ & Doğal logaritma \\
\hline
\end{tabular}

Veriler 1970-2017 yılları için derlenmiş olup veri kalitesi dikkate alınarak 36 OECD ülkesinden 28'i veri setine dahil edilmiştir. Bu kapsamda, Çekya, Slovakya, Slovenya, Letonya, Litvanya, Estonya, Polonya ve Macaristan ülkeleri analize dahil edilmeyen OECD ülkeleridir.

Reel GDP ve fiziki sermaye stoku verisi, 2011 yılı fiyatlarıyla US \$ olarak kullanılmıştır. Beşeri sermaye endeksi verisi yine Penn World Table veri setinden elde edilmiş olup söz konusu veri setinde bu endeks ortalama okullaşma yılı ile eğitimin geri dönüş oranına dayanmaktadır. Bu kapsamda ortalama okullaşma yılı Barro ve Lee (2013) ve Cohen ve Leker (2014) veri setine; eğitimin geri dönüş oranı ise Psacharopoulos (1994)'u takiben dünya ölçeğinde tahmin edilen Mincerian denklemine dayalı olarak elde edilmektedir (Human Capital in PWT 9.0). Çalışma kapsamında, istihdam edilen kişi sayısı beşeri sermaye endeksi dikkate alınarak ve Mincerian yaklaşım temelinde, nitelikli işgücü haline dönüştürülmüştür. $L$ vasıfsız işçi ve $H$ ortalama beşeri sermaye, $L H$ nitelik uyarlanmış işgücü olmak üzere $L H=L^{*} H$ olarak ifade edilmektedir (Caselli, 2005; Hall \& Jones, 1999; Şanlı, 2016). Ortalama eğitim yılı vasıfsız işgücüne nitelik kazandırmakta bu durumda nitelikli emeğin üretime katkısı da artmaktadır. Yani ortalama okullaşma yılındaki fazladan her bir yıl işgücünün üretime katkısını da artırmaktadır. Bu kapsamda, beşeri sermaye endeksi, ülkelere ilişkin istihdam verisi $L$ ile çarpılarak nitelik uyarlanmış işgücü verisi elde edilmiştir. Diğer yandan çalışmada üretim sınırı tahmin edileceği için ülkelerin ortalama yıllık çalışma saati verisi de analize dahil edilmiştir. 
Analizde kullanılan işgücü verisi nihai olarak $L H H=L^{*} H^{*} A V H$ şeklinde hesaplanmıştır. Regresyon tablolarında gösterim kolaylığı sağlaması nedeni ile $L H H$ değişkeni kısaca $L$ olarak ifade edilecektir.

SSA çerçevesinde yapılan hesaplamalarda kullanılan değişkenler Du (2017) çalışması izlenerek kendi ortalamalarıyla normalize edildikten sonra log değerleri esas alınarak kullanılmıştır. Değişkenlerin ölçeklendirilerek normalize edilmesi özellikle SSA yazınında sıklıkla kullanılmakta olan bir yöntemdir. Bu yöntem, çoklu doğrusal bağlantıyı zayıflatmak, değişen varyansı kontrol altına almak için önerilmektedir (Kim, 1999; Pablo-Romero \& Gomez-Calero, 2013; Kumbhakar, Lien \& Hardaker, 2014; Kumbhakar, Wang \& Horncastle, 2015). Bununla birlikte, normalizasyon, değişkenlerin birimlerinden arındırılmasını sağladığı için parametre değerlerinin de karşılaştırılabilir olmasına imkan sağlamaktadır (Wooldridge, 2003).

Çalışmada toplam faktör verimliliği büyümesi, SSA ile teknik etkinlik, teknik ilerleme ve ölçek etkinliği bileşenlerine ayrıştırılacaktır. Öncelikle Greene (2005a,b) takip edilerek etkinlik katsayıları tahmin edilecek ve uygun modelin tespitine yönelik olarak hipotez testleri yapılacaktır. Bu kapsamda, $i 28$ OECD ülkesini, $t$ ise zaman boyutunu göstermek üzere, üretim sınırını tahmin etmek için oluşturulan Cobb-Douglas ve translog üretim fonksiyonuna ilişkin kapalı ve açık fonksiyon formları 13 ila 16 nolu eşitlikler ile ifade edilmektedir. $\beta_{i j}$ ler tahmin edilecek parametre değerlerini, K ve L sırasıyla sermaye stoku ve işgücü saat cinsinden nitelikli emeği, $v_{i t}, 0$ ortalama $\sigma_{u}^{2}$ varyansa sahip rastgele hata terimini, $u_{i t}$ teknik etkinsizliği ifade etmektedir.

$\mathrm{t}=1,2,3, \ldots, \mathrm{T}(1970,1971,1972, \ldots, 2017$ y1lları için) trend değişkeni olmak üzere;

$$
\begin{gathered}
Y=f\{K, L, t\} \\
\ln \left(Y_{i t}\right)=\alpha_{0}+\beta_{1} \ln \left(K_{i t}\right)+\beta_{2} \ln \left(L_{i t}\right)+\beta_{3}(t)+v_{i t}-u_{i t} \\
Y=f\left\{K, L, t,(K \cdot L),(K \cdot t),(L \cdot t), K^{2}, L^{2}, t^{2}\right\} \\
\ln \left(Y_{i t}\right)=\alpha_{0}+\beta_{1} \ln \left(K_{i t}\right)+\beta_{2} \ln \left(L_{i t}\right)+\beta_{3}(t)+\beta_{12} \ln \left(K_{i t}\right) \ln \left(L_{i t}\right)+\beta_{13} \ln \left(K_{i t}\right) t+ \\
\beta_{23} \ln \left(L_{i t}\right) t+1 / 2 \beta_{11}\left(\ln K_{i t}\right)^{2}+1 / 2 \beta_{22}\left(\ln L_{i t}\right)^{2}+1 / 2 \beta_{33}(t)^{2}+v_{i t}-u_{i t}
\end{gathered}
$$

Etkinsizlik bileşeni $u_{i t}$ ise Battese and Coelli (1995)'i takiben 17 nolu eşitlikte belirtildiği şekilde tanımlanmaktadır. $\mu_{i t}$, kesikli normal dağılıma ve $\sigma_{u}^{2}$ varyansa sahip teknik etkinsizlik terimi $u_{i t}$ 'nin ortalamasını, $t$ trend değişkenini göstermektedir. $\delta$, teknik etkinsizlik ile ilişkili 
olarak tahmin edilecek parametre değerlerini, $w_{i t}$ ise etkinsizlik modeline ilişkin hata terimini göstermektedir.

$$
\mu_{i t}=\delta_{0}+\delta_{1} t+w_{i t}
$$

Diğer yandan, Kumbhakar vd., (2015)'i takiben, etkinsizlik terimi $u_{i}$ 'ye ilişkin varyans da trend değişkeninin fonksiyonu olarak 18 nolu eşitlikte ifade edildiği şekilde tanımlanmıştır.

$$
\sigma_{u i}^{2}=f(t)
$$

Tahmin edilen üretim sınırı denkleminde sermaye ve işgücü değişkenlerinin çıktı düzeyine etkisini gösteren katsayıların pozitif değerler $\frac{\partial \ln (Y)}{\partial \ln (K)}=\beta_{1}>0 ; \frac{\partial \ln (Y)}{\partial \ln (L)}=\beta_{2}>0$; etkinsizlik denkleminde yer almakta olan trend değişkeninin etkinsizlik düzeyine etkisini gösteren katsayının $\left(\frac{\partial \mu_{i t}}{\partial t}\right)$ ise negatif veya pozitif değerler alabileceği beklenmektedir.

TFV'nin bileşenleri belirlenirken hangi model spesifikasyonlarının kullanılacağına yapılacak hipotez testleri ile karar verilecektir. Bu kapsamda; etkinlik katsayılarının, "Sınır Yaklaşımı” ile mi yoksa "En Küçük Kareler Yöntemi” ile mi elde edileceğine; hangi üretim fonksiyonu ve dağılım formunun kullanılacağına; teknolojik değişimin karakteristik özelliğine LR testi ile karar verilecektir. LR testine ilişkin matematiksel form 19 nolu eşitlikte sunulmaktadir.

$$
L R=-2\left[\ln \left(L\left(H_{0}\right)\right)-\ln \left(L\left(H_{A}\right)\right)\right]
$$

$\ln \left(L\left(H_{0}\right)\right)$ kısıtlı modelin log-likelihood değerini, $\ln \left(L\left(H_{A}\right)\right)$ ise kısıtlanmamış modelin log-likelihood değerini ifade etmektedir. Hesaplanan LR test istatistikleri, Kodde ve Palm (1986) tarafından önerilen karma ki-kare dağılımının kritik değerlerini geçiyorsa $H_{0}$ reddedilmekte olup kısıtlanmamış modelin daha uygun olduğu sonucuna ulaşılmaktadır (Ahmadzai, 2017) .

Üretim fonksiyonunun ölçeğe göre getiri durumunu test etmek için ise Wald testi kullanılacaktır. Wald testinde $H_{0}$ hipotezi üretim fonksiyonunda ölçeğe göre sabit getiri olduğunu belirtmekte olup bu hipotez sınanacaktır. Etkinlik hesabında, TRE modelinin mi yoksa TFE modelinin mi tercih edileceğini belirlemeye yönelik olarak da Hausman testi yapilacaktır. Hausman testinde $H_{0}$ hipotezi rastgele etkiler modelinin etkin olduğunu; $H_{A}$ hipotezi ise sabit etkiler modelinin geçerli olduğunu ifade etmektedir Hausman testinde, olasılık değerinin 0,05 'ten küçük olması durumunda sabit etkiler modelinin kullanılması önerilmektedir (Reyna, 2007). 


\section{Ampirik Uygulama ve Bulgular}

$\mathrm{Bu}$ bölümünde, toplam faktör verimliliği büyümesi, SSA ile teknik etkinlik, teknik ilerleme ve ölçek etkinliği bileşenlerine ayrıştırılarak hesaplanacaktır. Kullanılan değişkenlere ilişkin özet istatistikler Tablo 2'de sunulmaktadır.

Tablo 2. Özet istatistiki veriler

\begin{tabular}{|c|c|c|c|c|c|c|c|}
\hline Değişkenler & Simge & Birim & $\begin{array}{c}\text { Gözlem } \\
\text { Sayısı }\end{array}$ & Ortalama & $\begin{array}{c}\text { Standart } \\
\text { Sapma }\end{array}$ & $\begin{array}{r}\text { Minimum } \\
\text { Değer }\end{array}$ & $\begin{array}{r}\text { Maksimum } \\
\text { Değer }\end{array}$ \\
\hline Reel GSYH & $\mathbf{Y}$ & Milyon USD \$ & 1.344 & 1.110 .000 & 2.190 .000 & 2.860 & 17.700 .000 \\
\hline Sermaye Stoku & $\mathbf{K}$ & Milyon USD \$ & 1.344 & 4.420 .000 & 7.710 .000 & 13.000 & 56.200 .000 \\
\hline İstihdam & $\mathbf{L}$ & Milyon Kişi & 1.344 & 16,20 & 25,50 & 0,09 & 154,00 \\
\hline Nüfus & $\mathbf{N}$ & Milyon Kişi & 1.344 & 36,90 & 54,50 & 0,20 & 324,00 \\
\hline Beşeri Sermaye & $\mathbf{H}$ & Endeks & 1.344 & 2,92 & 0,50 & 1,31 & 3,81 \\
\hline Çalışma Saati & AVH & Y1ll1k Ort. Saat & 1.333 & 1829,303 & 269,5552 & 1353,887 & 2910,735 \\
\hline
\end{tabular}

Not. Yazarın hesaplamaları.

Bu noktadan sonra öncelikle uygun modelin tespitine yönelik hipotez testleri yapılacaktır. Bu kapsamda, 7 adet hipotez testi tanımlanmıştır.

Hipotez Testi 1: İlk olarak, modelde birimler arası çıktı farkına neden olan bir etkinsizliğin olup olmadığı test edilmektedir. Boş hipotez, $H_{0}: \gamma=\delta_{0}=\delta_{1}=\ldots . \delta_{n}=0$ teknik etkinsizlik etkilerinin modelde her düzeyde bulunmadığı ve stokastik olmadığı şeklinde kurulmaktadır. Boş hipotez reddedilmezse, SSA, SEK (OLS) spesifikasyonuna indirgenmektedir. $\gamma 0$ ile 1 arasında değişmekte olup $\gamma=\frac{\sigma_{u}^{2}}{\sigma_{u}^{2}+\sigma_{v}^{2}}$ şeklinde tanımlanmaktadır. $\sigma_{u}^{2}$ etkinsizlik teriminin varyansını; $\sigma_{v}^{2}$ rasgele hata teriminin varyansını; $\sigma_{u}^{2}+\sigma_{v}^{2}$ ise birleşik hata teriminin varyansını göstermektedir (Batttese \& Coelli, 1995). $\gamma$ 1'e yaklaştıkça teknik etkinsizlikten kaynaklanan varyans ve SSA'ya uyum artmaktadır. Kumbhakar vd. (2015), uygun modelin belirlenmesi için LR test ile $H_{0}: \sigma_{u}^{2}=0$ hipotezinin sınanmasını önermekte olup bu kapsamda yapılmış olan hipotez testi, SSA'nın SEK'e tercih edilebilir olduğunu göstermiştir. Bu sonuç teknik etkinsizlik etkilerinin çıktı üzerinde anlamlı bir etkisi olduğu şeklinde yorumlanmaktadır ${ }^{11}$ (Tablo 3 ).

Hipotez Testi 2: Modele ilişskin bir diğer tercih noktası Cobb-Douglas ve translog üretim fonksiyonu arasında uygun fonksiyonel formun seçimidir. Cobb-Douglas üretim fonksiyonu formu, translog üretim fonksiyonu formunun özel bir durumudur. $H_{0}$ hipotezinin reddedilmesi

\footnotetext{
${ }^{11}$ Bu yaklaşım çerçevesinde, kısıtlı model SEK $\left(H_{0}\right)$ ve kısıtlanmamış model stokastik sınır $\left(H_{A}\right) \log$-likelihood değerleri esas alınarak LR test istatistiği hesaplanmaktadır. Burada serbestlik derecesi, testteki kısıtlamaların $\left(H_{0}: \sigma_{u}^{2}=0\right.$ 'ın sınanması durumunda 1 ) sayısına eşittir.
} 
durumunda üretim fonksiyonu formu translog olarak tercih edilmektedir. Uygun üretim fonksiyonu formunun seçimi LR test ile sınanmış olup $H_{0}$ hipotezi reddedilmiştir. Yani translog üretim fonksiyonu uygun üretim fonksiyonu formudur (Tablo 3).

Hipotez Testi 3: Bu kapsamda, etkinsizlik bileşeni için hangi dağılım formunun modele daha iyi uyum sağladığı test edilmektedir. Yarı normal dağılım, kesikli normal dağılımın özel bir durumu olduğundan ortalamanın sıfır olduğu yarı normal dağılım hipotezi test edilmektedir $^{12}$. LR test istatistiği, kritik değerden büyük olması nedeniyle $H_{0}$ hipotezi reddedilmiştir. Kesikli normal spesifikasyonu yarı normal spesifikasyona göre açıkça desteklemektedir (Tablo 3).

Hipotez Testi 4: Bu kapsamda, teknolojik değişimin olup olmadığı sınanmaktadır. Üretime katılan faktörlerin nasıl bir bileşime sahip olacağı üretim teknolojisi ile belirlenmektedir ${ }^{13}$ (Önder, Deliktaş \& Lenger, 2003). Tahmin sonuçlarına göre $H_{0}$ hipotezi reddedilmiş olup bu sonuç teknolojik değişimin olduğunu göstermektedir.

Hipotez Testi 5: Bu kapsamda, Hicks nötr teknolojik değişimin olup olmadığı sınanmaktadır. Nötr teknolojik değişim olması durumunda teknolojik değişme, üretim faktörü oranlarını, faktörler arası marjinal ikame oranlarını ve ölçeğe göre getiri durumlarını değiştirmemekte, eş ürün eğrileri orijine doğru paralel bir şekilde kaymaktadır. Kurulan hipotez testinde $H_{0}$ hipotezi reddedilmiştir. Bu sonuç, Hiks nötr teknolojik değişimin olmadığını yani teknolojik değişim sonrası üretim faktörlerinin marjinal verimliliğinin aynı oranda değişmediğini göstermektedir (Tablo 3).

Hipotez Testi 6: Üretim fonksiyonunun ölçeğe göre sabit, artan veya azalan getiri gösterip göstermediğini test etmek için Wald testi kullanılmaktadır (Ahmadzai, 2017). Modelde, $H_{0}$ hipotezi reddedilmiş olup bu sonuç ölçeğe göre sabit getirinin olmadığını göstermektedir (Tablo 3).

Hipotez Testi 7: İlk altı hipotez testinde varsayımsal olarak TFE modeli sınanmış olup son aşama olarak da TFE ile TRE modelleri kıyaslanarak uygun yöntem tespit edilecektir. Kalirajan ve Shand (1999)'u takiben TRE mi yoksa TFE yönteminin kullanılacağına Hausman testi sonucunda karar verilmektedir. $\mathrm{Bu}$ testte, $H_{0}$ hipotezi TRE modelinden elde edilen

\footnotetext{
${ }^{12}$ Kumbhakar, Wang, \& Horncastle (2015)'de yarı normal ve üstel dağılımların oldukça yakın olduğu ve iki modelden benzer tahmini verimlilik seviyelerinin görülebileceği belirtilmektedir. Buna bağlı olarak, yarı normal ve üstel dağılımlardan hangisinin tercih edileceğine ilişkin olarak ilave bir test yapılmayacak hipotez, yarı normal ve kesikli normal dağılım arasında sinama yapilacaktır.

${ }^{13}$ Üretim fonksiyonunun içerisine zaman faktörü eklendiğinde diğer faktörlerden bağımsız olarak, teknoloji faktörü fonksiyona dahil edilmiş olmaktadır.
} 
katsayıların etkin olduğunu; $H_{A}$ hipotezi ise TFE modelinin geçerli olduğunu ifade etmektedir. Hausman test sonucuna göre $H_{0}$ hipotezi reddedilmekte olup TFE modelinin geçerli olduğuna karar verilmektedir (Tablo 3).

$\mathrm{Bu}$ aşamaya kadar yapılmış olan 7 hipotez testinde boş hipotezler reddedilmiş olup hipotez testlerine ilişkin sonuçlar Tablo 3’te sunulmaktadır.

Tablo 3. Model Spesifikasyon Testleri

\begin{tabular}{|c|c|c|c|c|c|}
\hline No & $\mathbf{H}_{0}$ Hipotezi & $\begin{array}{c}\text { Log } \\
\text { Likelih } \\
\text { od }\end{array}$ & $\begin{array}{l}\text { LR test } \\
\text { istatistiğ } \\
\text { i }\end{array}$ & $\begin{array}{c}\text { Kriti } \\
\mathbf{k} \\
\text { Değer }\end{array}$ & Karar \\
\hline 1 & $\begin{array}{l}\text { Etkinsizlik Yok } \\
H_{0}: \sigma_{u}^{2}=0\end{array}$ & 492,1 & 2521,8 & 2,71 & $\begin{array}{c}H_{0} \text { Red } \\
\text { SSA Uygun }\end{array}$ \\
\hline 2 & $\begin{array}{l}\text { Cobb-Douglas Üretim Fonksiyonu } \\
H_{0}: \beta_{11}=\beta_{12}=\beta_{13}= \\
\beta_{22}=\beta_{23}=\beta_{33}=0\end{array}$ & 1.524 & 456,7 & 11,91 & $\begin{array}{c}H_{0} \text { Red } \\
\text { Translog Model Uygun }\end{array}$ \\
\hline 3 & $\begin{array}{l}\text { Yar1 Normal } \\
H_{0}: u_{i} \sim i i d N^{+}\left(0, \sigma_{u}^{2}\right)\end{array}$ & $1.741,4$ & 23,3 & 5,14 & $\begin{array}{c}H_{0} \text { Red } \\
\text { Kesikli Normal } \\
\text { Dağılım Uygun } \\
\end{array}$ \\
\hline 4 & $\begin{array}{l}\text { Hiksgil Nötr Teknolojik değişim } \\
\text { Var } \\
H_{0}: \beta_{13}=\beta_{23}=0\end{array}$ & $1.724,8$ & 56,3 & 5,14 & $\begin{array}{c}H_{0} \text { Red } \\
\text { Nötr Teknolojik Değişim } \\
\text { Yok }\end{array}$ \\
\hline 5 & $\begin{array}{l}\text { Teknolojik değişim Yok } \\
H_{0}: \beta_{3}=\beta_{13}=\beta_{23}=\beta_{33}=0\end{array}$ & $1.698,6$ & 108,7 & 8,76 & $\begin{array}{c}H_{0} \text { Red } \\
\text { Teknolojik Değişim Var }\end{array}$ \\
\hline 6 & $\begin{array}{l}\text { Ölçeğe Göre Sabit Getiri var } \\
H_{0}: \sum_{i}^{n} \beta_{i}=0\end{array}$ & $\operatorname{Wald}(\lambda$ & $\left.{ }^{2}\right)=191,4$ & & $\begin{array}{c}H_{0} \text { Red } \\
\text { Ölçeğe Göre Sabit Getiri } \\
\text { Yok }\end{array}$ \\
\hline 7 & $H_{0}:$ TRE Geçerli & $\begin{array}{l}\text { Chi2(7) } \\
\text { Prob>Cl}\end{array}$ & $\begin{array}{l}=209,01 \text {; } \\
\text { i2 } 0,000\end{array}$ & & $\begin{array}{c}H_{0} \text { Red } \\
\text { TFE Geçerli }\end{array}$ \\
\hline
\end{tabular}

Not. Tüm testler için Prob $>$ Chi2 $=0,0000$

Yapılan hipotez testi sonuçları, kesikli normal dağılım varsayımına dayanan etkinsizlik terimine, teknolojik değişime sahip translog SSA'nın uygun bir spesifikasyon olduğuna ve maksimum olasılık prosedürlerini içeren TFE modeli ile katsayı tahmininin yapılması gerektiğine işaret etmektedir. TFE ve TRE'ye ilişkin olarak yapılan regresyon tahmini sonuçları Tablo 4'te sunulmaktadır.

Tablo 4'te yer alan hem TRE hem de TFE modelinden ${ }^{14}$ elde edilen tahmin katsayıları incelendiğinde katsayı işaretlerinin trend değişkeni dışında aynı ve büyüklük olarak da yakın olduğu görülmektedir. Her iki modelde de $\mathrm{K}$ ve L katsayı tahminlerinin işaretleri iktisat

\footnotetext{
${ }^{14}$ TRE ve TFE modelleri genel olarak katsayı işaretleri ve büyüklükleri açısından benzer eğilimler taşımaktadır. Ancak t değişkeninin işaretinde majör farklar bulunmaktadır. Buna bağlı olarak hangi modelin tercih edilmesi gerektiği önemli bir karar noktası olarak karşımıza çıkmaktadır.
} 
teorisiyle uyumlu olarak, beklendiği gibi pozitif değerlidir. Katsayıların işaretinin pozitif olması, daha fazla K ve L kullanımının çıktıyı da artıracağı anlamına gelmektedir. Yine bu katsayılar \%1 anlamlılık seviyesinde elde edilmiştir.

Tablo 4. TFE-TRE SSA Tahmin Sonuçları

\begin{tabular}{|c|c|c|c|}
\hline Değişkenler & & TRE & TFE \\
\hline \multicolumn{4}{|l|}{ FRONTIER } \\
\hline \multirow[t]{2}{*}{$\ln (\mathrm{K})$} & $\beta_{1}$ & $0,700 * * *$ & $0,529 * * *$ \\
\hline & & $(0,00787)$ & $(0,0244)$ \\
\hline \multirow[t]{2}{*}{$\ln (\mathrm{L})$} & $\beta_{2}$ & $0,265^{* * *}$ & $0,179 * * *$ \\
\hline & & $(0,00732)$ & $(0,0188)$ \\
\hline \multirow[t]{2}{*}{$\mathrm{t}$} & $\beta_{3}$ & $-0,0570$ & $0,00861 * * *$ \\
\hline & & $(2,543)$ & $(0,000799)$ \\
\hline \multirow[t]{2}{*}{$\ln (\mathrm{K}) \ln (\mathrm{L})$} & $\beta_{12}$ & $0,0948 * * *$ & $0,120 * * *$ \\
\hline & & $(0,0123)$ & $(0,0175)$ \\
\hline \multirow[t]{2}{*}{$\ln (\mathrm{Kt})$} & $\beta_{13}$ & $7,16 e-05$ & $0,00485 * * *$ \\
\hline & & $(0,000465)$ & $(0,000680)$ \\
\hline \multirow[t]{2}{*}{$\ln (\mathrm{Lt})$} & $\beta_{23}$ & $-0,00106^{* *}$ & $-0,00242 * * *$ \\
\hline & & $(0,000428)$ & $(0,000558)$ \\
\hline \multirow[t]{2}{*}{$\mathrm{t}^{2}$} & $\beta_{33}$ & $-9,05 \mathrm{e}-05 * * *$ & $0,000177 * * *$ \\
\hline & & $(2,99 \mathrm{e}-05)$ & $(4,72 \mathrm{e}-05)$ \\
\hline \multirow[t]{2}{*}{$(\operatorname{lnK})^{2}$} & $\beta_{11}$ & $-0,0366 * * *$ & $-0,204 * * *$ \\
\hline & & $(0,0140)$ & $(0,0219)$ \\
\hline \multirow[t]{2}{*}{$(\operatorname{lnL})^{2}$} & $\beta_{22}$ & $-0,195 * * *$ & $-0,187 * * *$ \\
\hline & & $(0,0117)$ & $(0,0199)$ \\
\hline Sabit Terim & $\alpha_{0}$ & 0,552 & ----- \\
\hline \multicolumn{4}{|l|}{$\mu(\underline{M U})$} \\
\hline \multirow[t]{2}{*}{$\mathbf{t}$} & $\delta_{1}$ & $-0,0598$ & $0,0506^{* * *}$ \\
\hline & & $(2,543)$ & $(0,0140)$ \\
\hline \multirow[t]{2}{*}{ Sabit Terim } & $\delta_{0}$ & $1,918 * * *$ & $-0,990 * * *$ \\
\hline & & $(0,0196)$ & $(0,344)$ \\
\hline \multicolumn{4}{|l|}{$U_{\text {SiGMA }}$} \\
\hline \multirow[t]{2}{*}{$\mathbf{t}$} & & $-0,177 * * *$ & $-0,0615 * * *$ \\
\hline & & $(0,0169)$ & $(0,00457)$ \\
\hline \multirow[t]{2}{*}{ Sabit Terim } & & $-7,729 * * *$ & $-3,038 * * *$ \\
\hline & & $(0,312)$ & $(0,307)$ \\
\hline \multicolumn{4}{|l|}{$V_{\text {SIGMA }}$} \\
\hline Sabit Terim & & $\begin{array}{l}-5,676^{* * *} \\
(0,0596)\end{array}$ & $\begin{array}{l}-6,473 \text { *** } \\
(0,143)\end{array}$ \\
\hline$\sigma_{u}$ & & 0,040 & 0,238 \\
\hline$\sigma_{u}$ & & 0,059 & 0,039 \\
\hline$\gamma$ & & 0,319 & 0,973 \\
\hline Gözlem & & 1.333 & 1.333 \\
\hline Yatay Kesit & & 28 & 28 \\
\hline Prob > & & 0,0000 & 0,0000 \\
\hline
\end{tabular}


Not. Yazarın hesaplamaları. Parantez içi değerler standart hataları göstermektedir. $* * * p<0,01, * * p<0,05, *$ $\mathrm{p}<0,1$

Hem TRE hem de TFE modelinde, incelenen dönem çerçevesinde 28 OECD ülkesi için çıktı üzerinde etki gücü en yüksek değişken sermaye stokudur. Bu sonuç, sermaye stoku yüksek olan ülkelerin düşük olan ülkelere kıyasla daha fazla çıktı elde edeceği anlamı taşımaktadır. Sermaye stokunda meydana gelen $\% 1$ 'lik her artış çıktı düzeyinde yaklaşık olarak $\% 0,53$ 'lük (TRE modelinde \%0,70) bir artışa neden olmaktadır. Katsayının 1'den küçük olması, sermaye stokundaki büyümenin çıktı düzeyi üzerinde kendisi kadar bir etki yaratmadığını göstermektedir. L değişkeni nitelikli işgücünün toplam çalışma saatini içermekte olup nitelikli işgücünün toplam çalışma saatinde meydana gelen $\% 1$ 'lik her artış çıktı düzeyinde yaklaşık olarak \%0,18'lik (TRE modelinde \%0,27) bir artışa neden olmaktadır.

Teknolojik ilerlemenin vekil (proxy) değişkeni olarak kabul edilen trend değişkeni t'nin yönü ise modellerde farkl1lık göstermektedir. TFE modelinde pozitif ve $\% 1$ seviyesinde anlamlıdır. Yani TFE modelinde bu dönemde (48 yıllık zaman aralığında) pozitif ve anlamlı bir teknolojik ilerleme meydana geldiği söylenebilmektedir (TRE modelinde ise negatiftir ancak anlamlı bulunmamıştı).

Translog üretim fonksiyonunun uygun üretim formu tercih edilmesine bağlı olarak modelde $\mathrm{K}$ ve $\mathrm{L}$ ile t'ye ilişkin etkileşim terimleri de yer almaktadır. Fiziki sermaye ile nitelik uyarlanmış işgücü ve $t$ etkileşim değişkeni pozitif; nitelik uyarlanmış işgücü ile $t$ etkileşim değişkeni ise negatif değer almıştır. Etkileşim değişkenlerinin pozitif değer alması tamamlayıcılık ilişkisinin; negatif değer alması ise ikame ilişkisinin bir göstergesidir. $\beta_{12}$ nin pozitif olmasına bağlı olarak sermaye ile nitelikli işgücü arasında tamamlayıcıllk ilişkisi bulunmaktadır. TFE modelinde $\beta_{3}$ ve $\beta_{33}$ katsayılarının pozitif olması teknik ilerlemenin nötr kısmının üretim üzerinde olumlu etkilere sahip olduğunu göstermektedir. TRE modelinde ise bu katsayılar negatiftir. Bu durum teknik ilerlemenin nötr kısmının üretim üzerinde olumsuz etkilere sahip olduğunu ve pozitif teknik ilerleme sağlamak için, teknik ilerlemenin tarafsız olmayan kısmının bu etkileri dengelemesi gerektiğini göstermektedir.

$\beta_{13}$ ve $\beta_{23}$ katsayıları, sırasıyla $K \cdot t$ ve $L \cdot t$ 'nin işaretlerini göstermekte olup teknik ilerlemenin nötr olmayan kısmına denk gelmektedir. $\beta_{13}$ ’ün pozitif olması teknik ilerlemenin tarafsız olmayan kısmının sermaye birikimi ile birlikte hareket ettiğini; $\beta_{23}$ 'ün negatif olması teknik ilerlemenin tarafsız olmayan kısmının işgücü arzıyla ters yönde hareket ettiğinini göstermektedir. Bu durumda teknik ilerleme emek tasarrufu edici olup sermayenin bol olduğu ülkelerde daha yoğun olarak gerçekleşmektedir. Bu katsayılar hem TRE hem de TFE modelinde 
aynı yönlü tahmin edilmiş olup TFE modelinde her ikisi de \%1 seviyesinde anlamlı bulunmuştur.

Translog üretim fonksiyonunda etkileşim terimlerinin yanı sıra değişkenlere ilişkin kuadratik terimler de modele girmektedir. Kuadratik terimlere ilişkin katsayılar \% 1 seviyesinde anlamlı bulunmuş olup bu durum girdiler ile çıktı arasında doğrusal olmayan bir ilişkinin varlığını göstermektedir.

Modeldeki teknik etkinsizliği göstermekte olan $\mu(\mathrm{Mu})$, sadece kesikli normal dağılımda yer almakta olan $\left(u_{i} \sim i i d N^{+}\left(\mu, \sigma_{u}^{2}\right)\right)$ bir değişken olup modelde teknik etkinsizlik, trend değişkeninin bir fonksiyonu olarak belirlenmiştir. Wang (2002), $\mu(\mathrm{mu})$ ve $\sigma_{u}^{2}$ nin her ikisinin de aynı değişkenlerin fonksiyonu olarak tanımlanmasının bu değişkenlerin etkinsizlik üzerindeki etkilerinin kısıtlarını azaltacağını belirtmektedir. Wang (2002)'yi takiben $\mu$ (mu) ve $\sigma_{u}^{2}$ aynı değişkenlerin fonksiyonu olarak tanımlanmıştır. Modeldeki teknik etkinsizlik Mu'ye ilişkin olarak kurulan TFE modelinde, trend değişkeni pozitif işaretli ve istatistiksel olarak anlamlı tahmin edilmiştir. Açıklayıcı değişkenler etkinsizlikle ilişkili olduğu için negatif değerler etkinliği artırıcı, pozitif değerler etkinliği azaltıcı nitelik taşımaktadır. Buna göre TFE modelinde $\mathrm{t}$ arttıkça teknik etkinsizlik de ortalama \%0,05'lik bir artış göstermektedir. Yani bu durum teknik etkinliğin zamanla azaldığı anlamı taşımaktadır. Bu sonuç net bir şekilde teknik etkinlik katsayılarında da gözlenmektedir (TRE modelinde $\mathrm{t}$ arttıkça teknik etkinsizlik ortalama $\% 0,06$ azalmaktadir).

Etkinsizlik ve rassal hata bileşenlerine ilişskin varyans parametreleri de modellenmiş olup her iki hata terimine ilişkin tahminler hem TFE hem de TRE modellerinde \%1 seviyesinde anlamlı bulunmuştur. Teknik etkinsizlik varyans fonksiyonuna ilişkin tahmin $U_{\text {SíGMA; }}$ rastgele hata terimi varyans fonksiyonuna ilişkin tahmin de Vsigma başlı̆̆ı altındadır. Varyans parametrelerine ilişkin pozitif (negatif) bir parametre tahmini, değişkenin artan kullanımının çıktıda/etkinlikte daha yüksek (düşük) bir varyansa neden olacağı anlamını taşımaktadır. Elde edilen katsayılara göre, $\mathrm{t}$ arttıkça (zaman ilerledikçe) teknik etkinlikteki değişkenlik ortalama olarak azalmaktadır (UsigMA' daki parametrelerin negatif olması nedeniyle). Hem TRE hem de TFE modelinde, teknik etkinsizlik varyans fonksiyonuna ilişkin olarak $\mathrm{t}$ değişkeninin negatif işaret aldığı yani t'deki ilerlemenin etkinsizlikte daha düşük bir varyansa neden olduğu görülmektedir.

Diğer yandan SSA yaklaşımında elde edilen varyans parametresi $\gamma$ 'nın değeri 0,973 olarak elde edilmiş̧tir. Bu sonuç, sınır modelinin uygunluğu için önsel bir bilgi olarak karşımıza 
çıkmakta olup ayrıca ülkelerin çıktı seviyelerinin analizinde etkinsizlik etkisinin oldukça önemli olduğu anlamına da gelmektedir.

Hausman testi sonucu uygun model spesifikasyonunun TFE olmasına bağlı olarak, bu model baz alınarak TFV'nin bileşenleri belirlenmiştir. Bu çerçevede, sırasıyla teknik etkinlik, teknolojik ilerleme ve ölçek etkinliği tahmin edilmiştir. Elde edilen teknik etkinlik katsayıları 0 ila 1 arasında değerler almakta olup oran 1'e ne kadar yakın olursa, ülkenin o kadar etkin olduğu şeklinde yorumlanmaktadır. Analiz dönemi olan 48 yıllık periyodda teknik etkinlik seviyesinin ortalama olarak 0,938 'e eşit olduğu hesaplanmıştır. Bu durum, ortalama olarak ülkelerin maksimum çıktının \%93,8'ini ürettiklerini ve buna bağlı olarak da teknik etkinsizlik nedeniyle potansiyel çıktının yaklaşık \%6,2'sini kaybettiklerini göstermektedir. Elde edilen bu bulgular Koop, Osıewalskı ve Steel (2000) ile Arcelus ve Arocena (2000) çalışmalarının bulguları ile uyumludur.

Y1llar itibarıyla incelendiğinde ise 1970 yılında 0,917 olan ortalama teknik etkinlik katsayısının 2000 yılına kadar artış göstererek en yüksek seviyesi olan 0,972'ye ulaştığı görülmektedir. Bu süreçte ara yıllarda azalışlar da söz konusu olmasına rağmen genel eğilim olarak bir artış söz konusudur. Bu tarihten sonra ise teknik etkinliğin ortalama olarak bir azalış trendine girdiği görülmektedir. Bu süreçte en derin azalış 2008 küresel ekonomik kriz sonrasında gerçekleşmiştir. Bu sonuçlar birlikte değerlendirildiğinde, teknik etkinliğin önce arttığı yani ülkelerin ortalama olarak potansiyel çıktılarının daha büyük bir kısmını üretmeye başladıkları; ortalama teknik etkinlik olarak 0,972 seviyeleri görüldükten sonra ise gittikçe potansiyellerinden uzaklaştıkları ve 2017 yılında da \%14,5 seviyesinde teknik etkinsizlik kaynaklı çıktı kayıpları yaşandığı söylenebilmektedir. Etkinlikteki değişmenin ülkelerin teknolojiye adapte olma performansının bir göstergesi olmasına bağlı olarak, 1970 yılından 2017 yılına gelindiğinde panel genelinde ülkelerin mevcut teknolojilerine adapte olma performansının 6,5 puan düştüğü görülmektedir (Ek Tablo 2). Bu bulgu, Fare vd. (1994) çalışmasının bulguları ile örtüşmektedir.

Ülke bazında incelendiğinde ise mevcut teknolojiyi kullanma potansiyeli en yüksek ülkenin İzlanda olduğu görülmektedir. İzlanda'yı Avusturya, Avustralya ve İsrail takip etmektedir. Diğer yandan Şili, Lüksemburg, Yunanistan ve İrlanda etkinliği en düşük olan ülkeler olarak görülmektedir. İrlanda ortalama etkinliği en düşük ülke olarak tespit edilmiş olmakla birlikte ülkenin ortalamasının, 1990’lı yıllara kadar göstermiş olduğu zayıf etkinlik seviyesi nedeniyle düşük olduğu; 1990'lı yıllardan sonra etkinlik derecesinin hızla arttığ görülmektedir. ABD ve Japonya'nın etkinlik açısından alt sıralarda yer alması bir diğer dikkat çekici nokta olarak karşımıza çıkmaktadır. Bu durum bu ülkelerin teknoloji lideri ülkeler olarak 
üretim sınırlarındaki ilerlemeye (adapte olma performansı açısından) yetişmekte daha zayıf kaldıklarını göstermektedir.

$u_{i t}$ teknik etkinsizliği göstermek üzere; toplam faktör verimliliğinin bir bileşeni olarak teknik etkinlikteki değişim elde edilmiştir (Desli, C. Ray \& Kumbhakar, 2003). Buna göre, 1970 ile 2017 yılları arasındaki teknik etkinlik değişiminin pozitif değer almasına bağlı olarak, İsrail, Kore, İsveç, İngiltere, ABD, Norveç ve İrlanda'da zaman içinde mevcut teknolojiye uyumun arttığı yani mevcut teknolojilerin daha etkin kullanıldığı görülmektedir. Diğer ülkelerde ise teknik etkinlik değişiminin negatif değer alması, bu ülkelerde zaman içinde etkinsizlik kayıplarının arttığı anlamını taşımaktadır (Ek Tablo 3).

TFV değişiminin bileşenlerinden bir diğeri ise teknolojik ilerlemedir ${ }^{15}$. Panelde yer alan tüm ülkeler için 1970-2017 yılları arasında yıllık ortalama teknoloji değişim oranı \%0,64 olarak gerçekleşmiş olup bu sonuç incelenen dönemde net bir şekilde teknolojik ilerlemenin gerçekleştiğini göstermektedir. Yani, üretim sınırı analiz dönemi boyunca genişlemiştir. 1970’li yıllardan 2017 yılına gelinceye kadar yıllık teknoloji değişim oranının, birbirini takip eden ardışık dönemlerde sürekli bir artış eğiliminde olduğu görülmekle birlikte, bu artış azalarak artan şeklinde gerçekleşmektedir (Ek Tablo 4). Dönem boyunca ortalama yıllık teknolojik değişim, \%1,4 ila -\%0,3 arasında değişmektedir. ABD, \%1,4'lük ortalama teknolojik değişiklikle en yüksek teknik ilerlemeyi sergilerken, İzlanda, ortalama -\%0,3'lük oranla yıllık teknik gerileme yaşayan ülke olmuştur. Bununla birlikte İzlanda'da 2000'li yıllardan sonra y1llık teknik ilerleme görülmeye başlamıştır. En yüksek teknolojik ilerlemeyi gösteren ülke sıralamasında ABD’yi İtalya, Almanya, Fransa, Japonya ve İngiltere izlemektedir. Yine Kore'nin de 1990'lı yıllardan sonra hızlı bir teknolojik ilerleme seyrine girdiği net bir şekilde görülebilmektedir. Türkiye ise yıllık ortalama $\% 0,6$ 'lık teknolojik ilerleme değeri ile 18. sırada yer almaktadır (Ek Tablo 5). Çalışmanın bu bölüme ilişkin bulguları, Koop, Osıewalskı ve Steel (2000), Forstner ve Isaksson (2002), Bos vd. (2010), Pires ve Garcia (2012) ve Hou vd. (2020) çalışmaları ile paralellik göstermektedir. TFV değişiminin son bileşeni ise ölçek etkinliğidir. Ölçek etkinliği, esneklik katsayıları ve girdi büyümesi/daralması dikkate alınarak üretim ölçeğindeki değişimin verimlilik üzerindeki etkisini göstermektedir. Ölçek etkinliğinin verimliliğe katkısı üretim teknolojisine bağlı olarak değişmektedir. Ölçeğe göre sabit getiri koşullarında girdi büyümesi veya daralması verimlilik değişimine katkıda bulunmadığı için ölçek etkinliği de 0 olacaktır. Ölçek esnekliğinin 1 den büyük olması durumunda ölçek

\footnotetext{
${ }^{15} \mathrm{Bu}$ bileşen, herhangi iki bitişik dönem arasındaki teknolojik değişim olarak doğrudan stokastik sınır üretim fonksiyonu tahmini parametrelerinden zaman göre kısmi türevi alınarak elde edilmiştir.
} 
verimlilik değişimine pozitif katkı sağlamakta; 1'den küçük olması durumunda ise ölçek verimlilik değişimini negatif olarak etkilemektedir (Kumbhakar \& Lovell, 2000). Panel geneli ve analiz edilen dönem için ölçeğe göre azalan getiri koşulları tespit edilmiş olup bu duruma bağlı olarak ölçek etkinliğinin işareti de negatif olarak bulunmuştur. Elde edilen bu sonuç, Golany ve Thore (1997a), Aguiar, Costa ve Silva (2017) ve Hou vd. (2020) çalışmalarının bulguları ile örtüşmektedir.

İzlanda, Lüksemburg, Yeni Zelanda, İrlanda ve İsrail ölçeğe göre artan getiri sonuçlarına bağlı olarak ölçek etkinliğinin verimliliğe katkısı pozitif olarak bulgulanan ülkeler olup bu durum beklenen ve tutarlı bir sonuç olarak karşımıza çıkmaktadır. Finlandiya, Norveç ve Danimarka ise ölçeğe göre sabit getiri koşullarına ( $\varepsilon \cong 1$ ) bağlı olarak ölçek etkinliği 0 olarak bulgulanan ülkelerdir. Ölçeğe göre azalan getiri koşullarının geçerli olduğu diğer ülkelerde ise ölçek etkinliğinin verimliliğe katkısının negatif olduğu görülmektedir (Ek Tablo 6).

Teknik etkinlikteki değişim, teknolojik ilerleme ve ölçek etkinliği değişimi bileşenleri bir araya getirilerek TFV değişimi $(T F V C=T E C+T C+S C A L E)$ elde edilmiştir. TFV'de 19702017 dönemi arasında yıllık ortama \%0,13 artış meydana gelmiş olup 1970'li ve 1980'li yılların başı ile küresel krizin yaşandığg 2008-2009 yıllarında yıllık ortalama verimlilik düşüşü yaşandığı, en derin düşüşün ise \%2,25 ile 2009 yılında ortaya çıktığı görülmektedir. Bu yılların dışında birbirini izleyen dönemlerde verimlilik artışları ortaya çıkmıştır. İrlanda, İzlanda, Lüksemburg, Norveç, Belçika, İsveç, Danimarka, Hollanda, İsrail, Almanya, İngiltere, İsviçre, $\mathrm{ABD}$, Avusturya, Finlandiya ve Fransa panel ortalamasının üzerinde verimlilik büyümesi gösteren ülkeler olarak karşımıza çıkmaktadır. Türkiye'de ise 1970-2017 dönemi arasında TFV büyümesinde yıllık ortama \%0,38 oranında azalış meydana gelmiş olup özellikle sosyal, siyasal ve ekonomik risklerin arttığı dönemlerde derin düşüşlerin yaşandığı görülmektedir. Şöyle ki; siyasal risklerin yaşandığı 1980 yılında \%3,5; ekonomik krizlerin yaşandığı 1994 yılında \%4 ve 2001 yılında ise \%4,7 verimlilik düşüşü yaşanmıştır. Diğer yandan 1982-1987 dönemi ile 2002-2006 dönemi yüksek verimlilik büyümelerinin yaşandığ dönemler olarak karşımıza çıkmaktadır (Ek Tablo 7). Bu bulgular, Fare vd. (1994), Golany ve Thore (1997a), Kim, Park ve Park (2010), Bos vd. (2010), Aguiar, Costa ve Silva (2017), Heshmati ve Rashidghalam (2019) ve Hou vd. (2020) çalışmalarının bulguları ile benzeşmektedir.

Toplam faktör verimliliğindeki değişim ve bu değişimin kaynağını oluşturan 3 temel bileşen Tablo 5'te özet olarak sunulmaktadır. Tabloda da görüldüğü üzere, TFV büyüme oranları, teknik etkinlik ve teknolojik ilerlemenin ölçek etkinsizliğini telafi edemediği ülkelerde ortalama olarak negatif gerçekleşmiştir. Özellikle ölçeğe göre artan getiri koşullarına sahip ülkeler, daha düşük teknolojik ilerleme ve teknik etkinlik göstermiş olsalar da TFV büyümesi 
açısından diğer ülkelere kıyasla avantajlı konuma geçmiştir. Yine paneldeki ülkeler için, teknolojik değişimin, referans dönemi boyunca, yüksek TFV seviyelerine ulaşmanın temel belirleyici bileşeni olduğu görülmektedir.

Tablo 5. Toplam Faktör Verimliliği Büyümesinin Kaynakları (1970-2017; Y1llık Ortalama \%)

\begin{tabular}{lrrrr}
\hline Ülke & TFVC & TC & TEC & SCALE \\
\hline İrlanda & 1,04 & 0,33 & 0,48 & 0,23 \\
İzlanda & 0,90 & $-0,33$ & 0,05 & 1,18 \\
Lüksemburg & 0,77 & 0,16 & $-0,28$ & 0,89 \\
Norveç & 0,67 & 0,57 & 0,11 & $-0,01$ \\
Belçika & 0,62 & 0,81 & $-0,03$ & $-0,16$ \\
İsveç & 0,61 & 0,66 & 0,08 & $-0,14$ \\
Danimarka & 0,50 & 0,62 & $-0,07$ & $-0,04$ \\
Hollanda & 0,50 & 0,84 & $-0,04$ & $-0,30$ \\
İsrail & 0,49 & 0,32 & 0,08 & 0,18 \\
Almanya & 0,43 & 1,13 & $-0,05$ & $-0,65$ \\
İngiltere & 0,39 & 0,97 & 0,07 & $-0,65$ \\
İsviçre & 0,27 & 0,70 & $-0,26$ & $-0,17$ \\
ABD & 0,27 & 1,36 & 0,33 & $-1,42$ \\
Avusturya & 0,25 & 0,60 & $-0,19$ & $-0,16$ \\
Finlandiya & 0,23 & 0,44 & $-0,22$ & 0,00 \\
Fransa & 0,21 & 1,11 & $-0,21$ & $-0,70$ \\
Avustralya & $-0,03$ & 0,60 & $-0,09$ & $-0,54$ \\
Yeni Zelanda & $-0,03$ & 0,00 & $-0,29$ & 0,26 \\
Portekiz & $-0,07$ & 0,65 & $-0,57$ & $-0,16$ \\
İtalya & $-0,11$ & 1,15 & $-0,55$ & $-0,71$ \\
Kanada & $-0,14$ & 0,80 & $-0,20$ & $-0,74$ \\
İspanya & $-0,16$ & 0,96 & $-0,37$ & $-0,75$ \\
Yunanistan & $-0,24$ & 0,58 & $-0,64$ & $-0,18$ \\
Türkiye & $-0,38$ & 0,59 & $-0,04$ & $-0,93$ \\
Şili & $-0,49$ & 0,01 & $-0,40$ & $-0,10$ \\
Meksika & $-0,65$ & 0,69 & $-0,19$ & $-1,16$ \\
Japonya & $-0,86$ & 1,09 & $-0,35$ & $-1,61$ \\
Kore & $-1,12$ & 0,33 & 0,20 & $-1,66$ \\
\hline Genel Ortalama & $\mathbf{0 , 1 3}$ & $\mathbf{0 , 6 4}$ & $\mathbf{- 0 , 1 3}$ & $\mathbf{- 0 , 3 7}$ \\
\hline Not. Yazan & & & &
\end{tabular}

Not. Yazarın hesaplamaları

Amerika, İtalya, Almanya, Fransa, Japonya, İngiltere, İspanya en yüksek teknolojik ilerleme gösteren ülkeler olarak karşımıza çıkmaktadır. Paneldeki tüm ülkelerin İzlanda dışında teknolojik olarak ilerleme gösterdiği; Türkiye'nin ise teknolojik ilerleme açısından \% 0,59'luk ortalama ilerleme oranı ile yıllık ortalama \% 0,64 olan panel ortalamasının altında kaldığ görülmektedir. İrlanda, ABD, Kore, Norveç, İsveç, Israil, İngiltere ve İzlanda mevcut teknolojilerini zaman içinde en çok etkinleştiren yani üretim sınırlarına en çok yaklaşan ülkeler; İspanya, Şili, İtalya, Portekiz, Yunanistan ise üretim sınırından en çok uzaklaşan yani mevcut teknolojilerini etkin kullanmaktan uzaklaşan ülkeler olarak karşımıza çıkmaktadır. Türkiye ise yıllık ortalama \% 0,04 oranında üretim sınırından uzaklaşarak daha az etkin bir konuma gelmiştir. İzlanda, Lüksemburg, Yeni Zelanda, İrlanda, İsrail ve Finlandiya ölçek etkinliğinin 
verimliliğe katkısının pozitif olduğu ülkelerdir. Türkiye ise ölçek etkinliği değişiminin yıllık ortalama \% 0,93 oranı ile verimlilik değişimine negatif etkide bulunan ülkeler arasında yer almaktadır.

Teknolojik ilerleme, teknik etkinlik değişimi ve ölçek etkinliğinin toplamından oluşan toplam faktör verimliliği değişimi açısından değerlendirildiğinde ise 28 ülkenin 15 'inde yıllık ortalama olarak verimlilik artışı görülmektedir. İrlanda, İzlanda ve Lüksemburg ölçeğe göre artan getiri koşullarına bağlı olarak ölçek etkinliğinin verimliliğe büyük oranlı ve pozitif katkısına bağlı olarak ilk 3 sırada yer almaktadır. Norveç, Belçika, İsveç, Danimarka, Hollanda, İsrail, Almanya, İngiltere, İsviçre, ABD, Avusturya, Finlandiya ve Fransa analiz dönemi boyunca verimlilik artışı yaşayan diğer ülkelerdir. Japonya ve Kore yüksek teknolojik ilerleme kaydetmesine rağmen ölçek etkinliğinin negatif yansımasına bağlı olarak verimlilik düşüşü yaşayan ülkeler arasında yer almıştır. Analiz döneminde hem teknolojik ilerleme hem de teknik etkinlik artışı yaşayan ülkeler ise İrlanda, ABD, Kore, Norveç, İsveç, İsrail ve İngiltere olarak bulgulanmıştır. Türkiye ise yıllık ortalama \%0,38 verimlilik düşüşü yaşamış olup bu düşüş, ölçek etkinsizliği ve teknik etkinsizliğin artmasına bağlı olarak yaşanmıştır.

\section{Sonuç}

Çalışma kapsamında, 1970-2017 dönemine ilişkin olarak 28 OECD ülkesi için toplam faktör verimliliği büyümesi teknik etkinlik, teknolojik ilerleme ve ölçek etkinliği bileşenlerine ayrıştırılarak analiz edilmiştir. İrlanda, ABD, Kore, Norveç, İsveç, Israil, İngiltere ve İzlanda mevcut teknolojilerini zaman içinde en çok etkinleştiren yani üretim sınırlarına en çok yaklaşan ülkeler; İspanya, Şili, İtalya, Portekiz, Yunanistan ise üretim sınırından en çok uzaklaşan yani mevcut teknolojilerini etkin kullanmaktan uzaklaşan ülkeler olarak karşımıza çıkmaktadır. Türkiye ise yıllık ortalama \% 0,04 oranında üretim sınırından uzaklaşarak daha az etkin bir konuma gelmiştir. Panel genelinde ise, 1970 yılından 2017 yılına gelindiğinde ülkelerin mevcut teknolojilerine adapte olma performansının 6,5 puan düştüğü tespit edilmiştir. Bu durum, etkinsizlik kaynaklı üretim kayıplarında artışın meydana geldiği anlamını taşımakta olup ülkelerin mevcut teknolojilerini kullanabilme potansiyellerini artırmasının ekonomik büyüme açısından önemli bir firsat olduğunu göstermektedir. Bu kapsamda, özellikle yeni teknolojilerin öğrenilmesi ve öğretilmesini içeren eğitim süreci büyük önem taşımaktadır. Geliştirilmiş olan teknolojilerin yenilikçi ürün ve üretim süreçlerine dönüştürülerek ticarileşmesi, bu teknolojilere adapte olabilme yeteneği ile sınırlıdır. Yeni teknolojilere yönelik olarak yeteneklerinin geliştirilmesi ve farkındalığın artırılması da hayat boyu eğitim süreçlerinin etkinleştirilmesini gerektirmektedir. 
Yine 1970-2017 yılları arasındaki dönemde panelde yer alan tüm ülkeler için yıllık ortalama teknoloji değişim oranı \%0,64 olarak gerçekleşmiş olup bu sonuç incelenen dönemde teknolojik ilerlemenin gerçekleştiğini göstermektedir. Yani, üretim sınırı analiz dönemi boyunca genişlemiştir. Amerika, İtalya, Almanya, Fransa, Japonya, İngiltere, İspanya en yüksek teknolojik ilerleme gösteren ülkeler olarak karşımıza çıkmaktadır. Paneldeki tüm ülkelerin İzlanda dışında teknolojik olarak ilerleme gösterdiği; Türkiye'nin ise teknolojik ilerleme açısından \% 0,59'luk ortalama ilerleme oranı ile panel ortalamasının altında kaldığı görülmektedir. Bu bulgular, TFV'nin yüksek gelirli ülkelerde temel belirleyicisinin teknolojik ilerleme olduğunu göstermektedir. Bu bulgular aynı zamanda, gelişmiş ülkelerin, teknolojik ilerleme ile dünyanın üretim sınırını genişleterek dünya ekonomisine öncülük ettiğine işaret etmektedir. Teknolojik gelişmenin toplam faktör verimliliği ve büyüme için temel belirleyici bileşen olduğu dikkate alındığında, teknolojik ilerlemeyi motive edecek bir ekosistemin inşası ve bu yapının sürekliliğini sağlayacak unsurlar önem kazanmaktadır. Teknolojik ilerlemeyi motive edecek yenilikçi bir ekosistem ise sosyal, siyasal, kültürel ve makroekonomik değişkenler tarafından belirlenmektedir. Bu ekosistemde, Ar-Ge ve yenilik yapma kapasitesinin artırılması, risk sermayesi ve melek yatırımcılığın geliştirilmesi, teknolojik gelişmeleri sağlayacak ve bu gelişmelere ayak uydurabilecek insan kaynağının yetiştirilebilmesine destek olacak eğitim politikaları ile üniversitelerin araştırma altyapıları bakımından desteklenmesi temel politika başlıkları olarak karşımıza çıkmaktadır. Ayrıca teknoloji transferlerine ve yeteneklerin geliştirilmesine katkı sağlayacak doğrudan yabancı yatırımların çekilmesi de önemli bir politika aracı olarak görülmektedir.

Diğer yandan, çalışmada, İzlanda, Lüksemburg, Yeni Zelanda, İrlanda, İsrail ve Finlandiya ölçek etkinliğinin verimliliğe katkısının pozitif olduğu ülkeler olarak tespit edilmiştir. Ölçeğe göre artan getiri koşullarına sahip olan bu ülkeler, daha düşük teknolojik ilerleme ve teknik etkinlik göstermiş olsalar da TFV büyümesi açısından diğer ülkelere kıyasla avantajlı konuma geçmiştir. Ölçek etkinsizliğinin olduğu ülkelerde, bu etkinsizlik teknik etkinlik ve teknolojik ilerleme ile telafi edilmediği takdirde TFV büyüme oranı negatif olarak gerçekleşmiştir. Bu durum özellikle ölçeğe göre azalan getiri koşullarının geçerli olduğu ekonomilerde teknik etkinlik ve teknolojik ilerleme ile bunların desteklenmesine yönelik politikaların önemini artırmaktadır.

Çalışma kapsamında hesaplanan son bileşen olan TFV'de ise panel geneli için yıllık ortama \%0,13 artış tespit edilmiştir. 1970’li ve 1980'li yılların başı ile küresel krizin yaşandığ 2008-2009 yıllarında yıllık ortalama verimlilik düşüşü yaşandığı, en derin düşüşün ise \%2,25 ile 2009 yılında ortaya çıktığı görülmektedir. İrlanda, İzlanda ve Lüksemburg, Norveç, Belçika, 
İsveç, Danimarka, Hollanda, İsrail, Almanya, İngiltere, İsviçre, ABD, Avusturya, Finlandiya ve Fransa analiz dönemi boyunca verimlilik artışı yaşayan diğer ülkelerdir. Türkiye'de ise bu dönemde TFV'de yıllık ortalama \%0,38 oranında azalış meydana gelmiş olup bu sonuç ölçek etkinsizliği ve teknik etkinsizliğin artmasına bağlı olarak yaşanmıştır. Türkiye'de özellikle sosyal, siyasal ve ekonomik risklerin arttığı dönemlerde derin düşüşlerin yaşandığ1 görülmektedir. Şöyle ki; siyasal risklerin yaşandığı 1980 yılında \%3,5; derin ekonomik krizlerin yaşandığı 1994 yılında \%4 ve 2001 yılında ise \%4,7 verimlilik düşüşü yaşanmıştır. Diğer yandan 1982-1987 dönemi ile 2002-2006 dönemi yüksek verimlilik büyümelerinin yaşandığ dönemler olarak karşımıza çıkmaktadır.

Sonuç olarak, TFV'deki büyümenin, teknik etkinlik ve ölçek etkinliğindeki iyileşmelerden ziyade, büyük ölçüde teknolojik ilerlemeye bağlı olduğu; yüksek kişi başı gelir düzeyine sahip ülkelerin de bu noktada hâkim konumda olduğu çalışmanın temel bulgusu olarak karşımıza çıkmaktadır. Teknolojik gelişmenin, tarihsel süreç içerisinde, birikimsel olarak meydana geldiği ve kendinden önceki bilgi birikimlerinin kullanılmasını içerdiği dikkate alındığında bu sonuç beklenen bir durumdur. Bununla birlikte teknik etkinlikteki potansiyel alan verimlilik artışı ve büyüme için önemli bir kaynak olarak görülmektedir. Bu noktada teknik etkinsizlikten kaynaklı üretim kaynaklarının azaltılması bir firsat olarak durmaktadır. Ancak yine de üretim sınırı dikkate alındığında teknolojik ilerleme başat aktör olarak karşımıza çıkmaktadır. Bu durumda, gerek teknik etkinliğin gerekse teknolojik ilerlemenin, dış dünyayla entegrasyon, bilginin yayılması, beşeri sermaye, finansal sistem, fiziki ve sosyal altyapı gibi ekonomik, sosyal ve çevresel belirleyicilerinin analizi önemli çalışma sorusu olarak araştırmacılarını beklemektedir. 


\section{Ekler}

Ek Tablo 1. Hausman Test Sonuçları

\begin{tabular}{|c|c|c|c|c|}
\hline & $\begin{array}{r}\text { (b) } \\
\text { TFE } \\
\end{array}$ & $\begin{array}{r}\text { (B) } \\
\text { TRE }\end{array}$ & (b-B) & S.E. \\
\hline $\ln (\mathrm{K})$ & 0,5295 & 0,7001 & $-0,1706$ & 0,0231 \\
\hline $\ln (\mathrm{L})$ & 0,1785 & 0,2655 & $-0,0870$ & 0,0173 \\
\hline $\mathrm{t}$ & 0,0086 & $-0,0570$ & 0,0656 & - \\
\hline $\ln (\mathrm{K}) \ln (\mathrm{L})$ & 0,1199 & 0,0948 & 0,0251 & 0,0124 \\
\hline $\operatorname{Ln}(\mathrm{Kt})$ & 0,0048 & 0,0001 & 0,0048 & 0,0005 \\
\hline $\operatorname{Ln}(\mathrm{Lt})$ & $-0,0024$ & $-0,0011$ & $-0,0014$ & 0,0004 \\
\hline $\mathrm{t} 2$ & 0,0002 & $-0,0001$ & 0,0003 & 0,0000 \\
\hline $\ln (\mathrm{K} 2)$ & $-0,2038$ & $-0,0366$ & $-0,1672$ & 0,0169 \\
\hline $\ln (\mathrm{L} 2)$ & $-0,1865$ & $-0,1947$ & 0,0082 & 0,0160 \\
\hline
\end{tabular}

S.E. $=\operatorname{sqrt}\left(\operatorname{diag}\left(\mathrm{V} \_\mathrm{b}-\mathrm{V} \_\mathrm{B}\right)\right) ; \mathrm{b}=H_{0}$ ve $H_{A}$ altında tutarlı; $\mathrm{B}=H_{A}$ altında tutarsız, $H_{0}$ altında etkin

Not. Yazarın hesaplamaları.

Ek Tablo 2. Y1llar İtibarıyla Ortalama Teknik Etkinlik Katsayıları

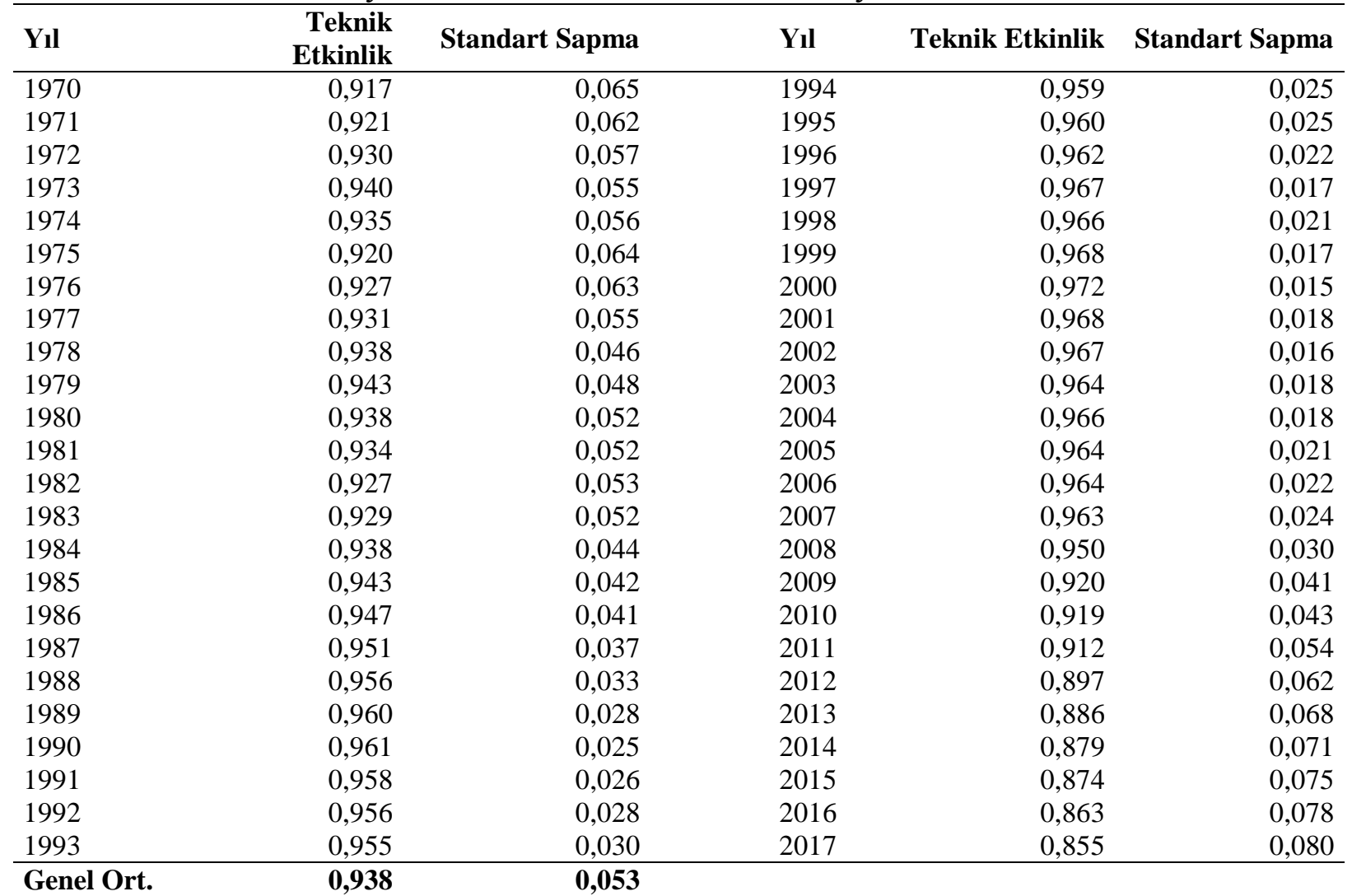

Not. Yazarın hesaplamaları. 
Ek Tablo 3. Ülkelere İlişkin Teknik Etkinlik Katsayıları

\begin{tabular}{|c|c|c|c|c|c|c|c|c|c|c|c|}
\hline Ülke & $\begin{array}{r}1970- \\
1974 \\
\end{array}$ & $\begin{array}{r}1975- \\
1979 \\
\end{array}$ & $\begin{array}{r}1980- \\
1984 \\
\end{array}$ & $\begin{array}{r}1985- \\
1989 \\
\end{array}$ & $\begin{array}{r}1990- \\
1994 \\
\end{array}$ & $\begin{array}{r}1995- \\
1999 \\
\end{array}$ & $\begin{array}{r}2000- \\
2004 \\
\end{array}$ & $\begin{array}{r}2005- \\
2009 \\
\end{array}$ & $\begin{array}{r}2010- \\
2014 \\
\end{array}$ & $\begin{array}{r}2015- \\
2017 \\
\end{array}$ & $\begin{array}{r}\text { Genel } \\
\text { Ort }\end{array}$ \\
\hline İzlanda & 0,967 & 0,971 & 0,970 & 0,962 & 0,931 & 0,943 & 0,957 & 0,963 & 0,947 & 0,965 & 0,957 \\
\hline Avusturya & 0,967 & 0,966 & 0,964 & 0,964 & 0,972 & 0,970 & 0,968 & 0,963 & 0,920 & 0,878 & 0,956 \\
\hline Avustralya & 0,949 & 0,950 & 0,943 & 0,958 & 0,956 & 0,975 & 0,980 & 0,973 & 0,947 & 0,913 & 0,956 \\
\hline İsrail & & & 0,899 & 0,944 & 0,974 & 0,971 & 0,959 & 0,969 & 0,968 & 0,944 & 0,955 \\
\hline Türkiye & 0,957 & 0,944 & 0,916 & 0,975 & 0,970 & 0,964 & 0,946 & 0,963 & 0,954 & 0,940 & 0,953 \\
\hline Kanada & 0,960 & 0,973 & 0,966 & 0,974 & 0,950 & 0,960 & 0,975 & 0,956 & 0,902 & 0,857 & 0,951 \\
\hline Hollanda & 0,922 & 0,957 & 0,945 & 0,957 & 0,969 & 0,975 & 0,980 & 0,971 & 0,920 & 0,883 & 0,951 \\
\hline Danimarka & 0,934 & 0,931 & 0,941 & 0,968 & 0,967 & 0,980 & 0,978 & 0,964 & 0,922 & 0,899 & 0,950 \\
\hline Kore & 0,897 & 0,968 & 0,913 & 0,974 & 0,972 & 0,949 & 0,967 & 0,966 & 0,958 & 0,932 & 0,950 \\
\hline İsviçre & 0,986 & 0,968 & 0,970 & 0,970 & 0,957 & 0,939 & 0,942 & 0,945 & 0,918 & 0,877 & 0,950 \\
\hline Almanya & 0,922 & 0,941 & 0,947 & 0,958 & 0,982 & 0,979 & 0,973 & 0,953 & 0,917 & 0,888 & 0,949 \\
\hline Meksika & 0,960 & 0,973 & 0,978 & 0,941 & 0,962 & 0,960 & 0,967 & 0,941 & 0,891 & 0,871 & 0,948 \\
\hline Fransa & 0,942 & 0,960 & 0,967 & 0,971 & 0,975 & 0,972 & 0,974 & 0,952 & 0,882 & 0,826 & 0,947 \\
\hline Belçika & 0,899 & 0,940 & 0,962 & 0,970 & 0,977 & 0,976 & 0,973 & 0,962 & 0,912 & 0,857 & 0,947 \\
\hline Finlandiya & 0,953 & 0,926 & 0,949 & 0,960 & 0,930 & 0,968 & 0,983 & 0,976 & 0,919 & 0,854 & 0,945 \\
\hline İsveç & 0,926 & 0,921 & 0,919 & 0,935 & 0,905 & 0,945 & 0,979 & 0,982 & 0,972 & 0,969 & 0,944 \\
\hline İngiltere & 0,907 & 0,900 & 0,907 & 0,959 & 0,956 & 0,973 & 0,982 & 0,978 & 0,946 & 0,924 & 0,944 \\
\hline Y, Zelanda & 0,985 & 0,969 & 0,973 & 0,958 & 0,934 & 0,954 & 0,958 & 0,932 & 0,885 & 0,858 & 0,944 \\
\hline İspanya & 0,963 & 0,971 & 0,968 & 0,978 & 0,975 & 0,967 & 0,964 & 0,932 & 0,815 & 0,773 & 0,937 \\
\hline Japonya & 0,952 & 0,932 & 0,957 & 0,981 & 0,984 & 0,973 & 0,945 & 0,906 & 0,842 & 0,806 & 0,933 \\
\hline $\mathrm{ABD}$ & 0,804 & 0,849 & 0,869 & 0,938 & 0,954 & 0,975 & 0,983 & 0,978 & 0,955 & 0,937 & 0,924 \\
\hline Portekiz & 0,985 & 0,973 & 0,960 & 0,960 & 0,973 & 0,963 & 0,938 & 0,881 & 0,795 & 0,734 & 0,924 \\
\hline İtalya & 0,963 & 0,973 & 0,977 & 0,979 & 0,976 & 0,969 & 0,949 & 0,878 & 0,765 & 0,708 & 0,922 \\
\hline Norveç & 0,816 & 0,869 & 0,895 & 0,932 & 0,956 & 0,983 & 0,985 & 0,971 & 0,903 & 0,847 & 0,918 \\
\hline Şili & 0,927 & 0,849 & 0,895 & 0,909 & 0,978 & 0,985 & 0,970 & 0,951 & 0,871 & 0,784 & 0,917 \\
\hline Lüksemburg & 0,888 & 0,808 & 0,830 & 0,941 & 0,982 & 0,979 & 0,981 & 0,957 & 0,861 & 0,800 & 0,907 \\
\hline Yunanistan & 0,986 & 0,987 & 0,965 & 0,925 & 0,896 & 0,894 & 0,941 & 0,941 & 0,751 & 0,685 & 0,906 \\
\hline İrlanda & 0,757 & 0,789 & 0,772 & 0,804 & 0,901 & 0,973 & 0,986 & 0,958 & 0,919 & 0,983 & 0,880 \\
\hline Genel Ort. & 0,929 & 0,932 & $\mathbf{0 , 9 3 3}$ & 0,952 & $\mathbf{0 , 9 5 8}$ & 0,965 & 0,967 & $\mathbf{0 , 9 5 2}$ & $\mathbf{0 , 8 9 8}$ & 0,864 & $\mathbf{0 , 9 3 8}$ \\
\hline
\end{tabular}

Not. Yazarın hesaplamaları. 
Ek Tablo 4. Yillar İtibarıla Ortalama Teknolojik İlerleme

\begin{tabular}{|c|c|c|c|c|c|}
\hline Yil & $\begin{array}{c}\text { Teknolojik } \\
\text { İlerleme } \\
\end{array}$ & Standart Sapma & Yil & $\begin{array}{c}\text { Teknolojik } \\
\text { İlerleme } \\
\end{array}$ & $\begin{array}{r}\text { Standart } \\
\text { Sapma } \\
\end{array}$ \\
\hline 1970 & - & - & 1994 & 0,0065 & 0,0041 \\
\hline 1971 & $-0,0007$ & 0,0042 & 1995 & 0,0067 & 0,0040 \\
\hline 1972 & $-0,0003$ & 0,0042 & 1996 & 0,0070 & 0,0040 \\
\hline 1973 & 0,0001 & 0,0042 & 1997 & 0,0073 & 0,0040 \\
\hline 1974 & 0,0005 & 0,0042 & 1998 & 0,0076 & 0,0040 \\
\hline 1975 & 0,0009 & 0,0043 & 1999 & 0,0078 & 0,0039 \\
\hline 1976 & 0,0012 & 0,0042 & 2000 & 0,0081 & 0,0039 \\
\hline 1977 & 0,0016 & 0,0042 & 2001 & 0,0084 & 0,0039 \\
\hline 1978 & 0,0019 & 0,0042 & 2002 & 0,0086 & 0,0039 \\
\hline 1979 & 0,0023 & 0,0042 & 2003 & 0,0089 & 0,0039 \\
\hline 1980 & 0,0026 & 0,0042 & 2004 & 0,0092 & 0,0039 \\
\hline 1981 & 0,0028 & 0,0042 & 2005 & 0,0095 & 0,0038 \\
\hline 1982 & 0,0031 & 0,0042 & 2006 & 0,0097 & 0,0038 \\
\hline 1983 & 0,0034 & 0,0042 & 2007 & 0,0100 & 0,0038 \\
\hline 1984 & 0,0036 & 0,0041 & 2008 & 0,0103 & 0,0038 \\
\hline 1985 & 0,0039 & 0,0042 & 2009 & 0,0106 & 0,0038 \\
\hline 1986 & 0,0041 & 0,0042 & 2010 & 0,0108 & 0,0038 \\
\hline 1987 & 0,0044 & 0,0041 & 2011 & 0,0110 & 0,0038 \\
\hline 1988 & 0,0047 & 0,0041 & 2012 & 0,0113 & 0,0038 \\
\hline 1989 & 0,0050 & 0,0041 & 2013 & 0,0115 & 0,0038 \\
\hline 1990 & 0,0053 & 0,0041 & 2014 & 0,0118 & 0,0038 \\
\hline 1991 & 0,0056 & 0,0041 & 2015 & 0,0120 & 0,0037 \\
\hline 1992 & 0,0059 & 0,0041 & 2016 & 0,0122 & 0,0037 \\
\hline 1993 & 0,0062 & 0,0041 & 2017 & 0,0125 & 0,0037 \\
\hline Genel Ort. & 0,0064 & 0,0055 & & & \\
\hline
\end{tabular}

Not. Yazarın hesaplamaları. 
Ek Tablo 5. Ülkelere İlişkin Teknolojik İlerleme

\begin{tabular}{|c|c|c|c|c|c|c|c|c|c|c|c|}
\hline Ülke & $\begin{array}{r}1970- \\
1974 \\
\end{array}$ & $\begin{array}{r}1975- \\
1979 \\
\end{array}$ & $\begin{array}{r}1980- \\
1984 \\
\end{array}$ & $\begin{array}{r}1985- \\
1989 \\
\end{array}$ & $\begin{array}{r}1990- \\
1994 \\
\end{array}$ & $\begin{array}{r}1995- \\
1999 \\
\end{array}$ & $\begin{array}{r}2000- \\
2004 \\
\end{array}$ & $\begin{array}{r}2005- \\
2009 \\
\end{array}$ & $\begin{array}{r}2010- \\
2014 \\
\end{array}$ & $\begin{array}{r}2015- \\
2017 \\
\end{array}$ & $\begin{array}{r}\text { Genel } \\
\text { Ort. }\end{array}$ \\
\hline $\mathrm{BD}$ & 00079 & 0,0091 & & 0,0117 & 0,0131 & 0,0143 & 0,0157 & 0,0171 & 0,0183 & 0,0191 & 0,0136 \\
\hline & & & & & & & & & & & \\
\hline & 050 & 066 & 082 & 0095 & 10 & & 37 & 0148 & 58 & 0167 & 113 \\
\hline & 046 & 063 & & & & & & 147 & & & \\
\hline & 028 & 052 & 0072 & 0,0090 & & 26 & & 151 & 61 & 69 & 109 \\
\hline & 040 & 0,0054 & 0,0068 & 0,0080 & 0,0094 & 06 & & 30 & 40 & 48 & 97 \\
\hline & & & & & & & & & & & \\
\hline & 026 & 042 & 056 & 69 & 81 & 91 & & 115 & 27 & & 084 \\
\hline & & & & & & & & & & & \\
\hline & & & & & & & & & & & \\
\hline & & 28 & 42 & 54 & & & & & & 20 & 970 \\
\hline & & & & & & & & & & & \\
\hline & & 28 & 0 & & & & & & & & 66 \\
\hline & & & & & & & & & & & \\
\hline & & & & & & & & & & & \\
\hline & & & & & & & & & & & \\
\hline & & & & & & & & & & & \\
\hline & & & & & & & & & & & \\
\hline & & & & & & & & & & & 58 \\
\hline & 07 & 11 & 28 & 42 & 55 & 66 & & 91 & & & 057 \\
\hline & & & & & & & & & & & 044 \\
\hline & & 59 & & & & & & & & & \\
\hline & 046 & $-0,0027$ & $-0,0005$ & & & & & & & & 033 \\
\hline & & & & & & & & & & & \\
\hline Lü & 36 & 24 & -0 & 02 & 13 & 24 & 35 & 46 & 57 & 65 & 016 \\
\hline & $-0,0063$ & $-0,0051$ & $-0,0039$ & $-0,0031$ & $-0,0016$ & & & & & & 001 \\
\hline & & & & & & & & & & & 0,0000 \\
\hline & $-0,0096$ & $-0,0079$ & $-0,0063$ & $-0,0051$ & $-0,0036$ & $-0,0025$ & $-0,0011$ & 0,0005 & 0,0016 & 0,0022 & $-0,0033$ \\
\hline Genel Ort & 001 & 0,0016 & 0,0031 & 0,0044 & 0,0059 & 0,0073 & 0,0086 & $\mathbf{0 , 0 1 0 0}$ & $\mathbf{0 , 0 1 1 3}$ & $\mathbf{0 , 0 1 2 2}$ & 0,0064 \\
\hline
\end{tabular}

Not. Yazarın hesaplamaları. 
Ek Tablo 6. Ülkelere İlişkin Ölçek Etkinliği Değişimi

\begin{tabular}{|c|c|c|c|c|c|c|c|c|c|c|c|}
\hline Ülke & $\begin{array}{r}1970- \\
1974 \\
\end{array}$ & $\begin{array}{r}1975- \\
1979 \\
\end{array}$ & $\begin{array}{r}1980- \\
1984 \\
\end{array}$ & $\begin{array}{r}1985- \\
1989 \\
\end{array}$ & $\begin{array}{r}1990- \\
1994 \\
\end{array}$ & $\begin{array}{r}1995- \\
1999 \\
\end{array}$ & $\begin{array}{r}2000- \\
2004 \\
\end{array}$ & $\begin{array}{r}2005- \\
2009 \\
\end{array}$ & $\begin{array}{r}2010- \\
2014 \\
\end{array}$ & $\begin{array}{r}2015- \\
2017 \\
\end{array}$ & $\begin{array}{r}\text { Genel } \\
\text { Ort. }\end{array}$ \\
\hline İzlanda & 0,024 & 0,016 & 0,016 & 0,012 & 0,006 & 0,012 & 0,010 & 0,010 & 0,002 & 0,011 & 0,012 \\
\hline Lüksemburg & 017 & 0,006 & 0,003 & 0,009 & 0,010 & 0,010 & 0,009 & 0,009 & 0,009 & 008 & 0,009 \\
\hline Yeni Zelanda & 0,005 & 0,003 & 0,002 & 0,002 & 0,002 & 0,003 & 0,003 & 0,002 & 0,002 & 0,002 & 0,003 \\
\hline İrlanda & 0,005 & 0,004 & 0,002 & 0,001 & 0,002 & 0,004 & 0,002 & 0,001 & 0,000 & 0,001 & 0,002 \\
\hline İsrail & & & 0,012 & 0,001 & 0,003 & 0,001 & 0,000 & 0,000 & 0,000 & $-0,001$ & 0,002 \\
\hline Finlandiya & 0,001 & 0,000 & 0,000 & 0,000 & 0,000 & 0,000 & 0,000 & 0,000 & 0,000 & 0,000 & 0,000 \\
\hline Norveç & 0,000 & 0,000 & 0,000 & 0,000 & 0,000 & 0,000 & 0,000 & 0,000 & 0,000 & 00 & 0,000 \\
\hline Dani & $-0,001$ & $-0,001$ & 0,000 & $-0,001$ & 0,000 & $-0,001$ & 0,000 & 0,000 & 0,000 & 0,000 & 0,000 \\
\hline Şili & 002 & 0,001 & 0,001 & 0,001 & 0,000 & $-0,001$ & $-0,002$ & 0,003 & 05 & -0 , & $-0,001$ \\
\hline İsveç &, 003 & $-0,002$ & $-0,002$ & $-0,003$ & 0,000 & $-0,001$ & $-0,001$ & $-0,001$ & $-0,001$ & $-0,001$ & $-0,001$ \\
\hline Belçika & $-0,003$ & $-0,002$ & $-0,001$ & $-0,001$ & $-0,001$ & $-0,002$ & $-0,002$ & $-0,002$ & $-0,001$ & $-0,001$ & $-0,002$ \\
\hline Avustur & 003 & $-0,002$ & $-0,001$ & $-0,002$ & $-0,002$ & $-0,002$ & $-0,001$ & $-0,001$ & $-0,001$ & $-0,001$ & $-0,002$ \\
\hline Port &, 001 & $-0,002$ & $-0,002$ & $-0,002$ & $-0,002$ & $-0,003$ & $-0,002$ & $-0,001$ & 0,000 & $-0,001$ & $-0,002$ \\
\hline & 003 & $-0,001$ & $-0,002$ & $-0,003$ & $-0,002$ & $-0,001$ & $-0,001$ & $-0,001$ & -0 , & -0 & 02 \\
\hline Yur & 003 & $-0,003$ & $-0,002$ & $-0,002$ & $-0,002$ & $-0,002$ & $-0,002$ & $-0,002$ & 0,001 & 0,000 & $-0,002$ \\
\hline Holl &, 005 & $-0,003$ & $-0,002$ & $-0,004$ & $-0,003$ & $-0,005$ & $-0,003$ & $-0,003$ & $-0,001$ & $-0,002$ & $-0,003$ \\
\hline Avı & 005 & $-0,005$ & $-0,005$ & $-0,006$ & $-0,004$ & $-0,006$ & $-0,006$ & $-0,007$ & $-0,006$ & $-0,005$ & $-0,005$ \\
\hline Alm & 016 & $-0,010$ & $-0,007$ & $-0,007$ & $-0,006$ & $-0,006$ & $-0,003$ & $-0,003$ & $-0,004$ & $-0,004$ & $-0,006$ \\
\hline Birle &, 011 & $-0,008$ & $-0,003$ & $-0,010$ & $-0,005$ & $-0,007$ & $-0,006$ & $-0,005$ & $-0,004$ & $-0,006$ & $-0,007$ \\
\hline Fransa & 014 & $-0,011$ & $-0,006$ & $-0,008$ & $-0,006$ & $-0,006$ & $-0,006$ & $-0,006$ & $-0,004$ & $-0,005$ & $-0,007$ \\
\hline &, 015 & $-0,011$ & $-0,010$ & $-0,009$ & $-0,006$ & $-0,006$ & $-0,007$ & $-0,005$ & 0,000 & $-0,003$ & $-0,007$ \\
\hline Kan & & $-0,009$ & $-0,007$ & $-0,009$ & $-0,005$ & $-0,007$ & $-0,007$ & $-0,007$ & $-0,007$ & $-0,006$ & $-0,007$ \\
\hline & 014 & $-0,007$ & $-0,002$ & $-0,008$ & $-0,007$ & $-0,010$ & $-0,012$ & $-0,010$ & $-0,001$ & $-0,005$ & $-0,008$ \\
\hline & & & & & $-0,009$ & & $-0,006$ & $-0,012$ & & $-0,017$ & $-0,009$ \\
\hline Meksika &, 015 & $-0,017$ & $-0,015$ & $-0,008$ & $-0,011$ & $-0,009$ & $-0,009$ & $-0,011$ & $-0,010$ & $-0,010$ & $-0,012$ \\
\hline $\mathrm{ABD}$ & $-0,018$ & $-0,017$ & $-0,014$ & $-0,018$ & $-0,013$ & $-0,017$ & $-0,016$ & $-0,013$ & $-0,007$ & $-0,008$ & $-0,014$ \\
\hline & $-0,046$ & $-0,029$ & $-0,021$ & $-0,022$ & $-0,019$ & $-0,012$ & $-0,006$ & $-0,003$ & $-0,001$ & $-0,003$ & $-0,016$ \\
\hline Kore Cum & $-0,005$ & $-0,015$ & $-0,015$ & $-0,021$ & $-0,029$ & $-0,023$ & $-0,017$ & $-0,013$ & $-0,011$ & $-0,011$ & $-0,017$ \\
\hline Genel Ort. & $-0,005$ & $-0,005$ & $-0,003$ & $-0,004$ & $-0,004$ & $-0,004$ & $-0,003$ & $-0,003$ & $-0,002$ & $-0,003$ & $-0,004$ \\
\hline
\end{tabular}

Not. Yazarın hesaplamaları. 
Ek Tablo 1. Yıllar İtibarıyla Toplam Faktör Verimliliğindeki Değişim

\begin{tabular}{|c|c|c|c|c|c|c|}
\hline Yıl & & $\begin{array}{r}\text { TFV } \\
\text { Değişimi }\end{array}$ & Standart Sapma & Yll & $\begin{array}{r}\text { TFV } \\
\text { Değişimi } \\
\end{array}$ & $\begin{array}{r}\text { Standart } \\
\text { Sapma } \\
\end{array}$ \\
\hline 1970 & -- & & -- & 1994 & 0,0065 & 0,0141 \\
\hline 1971 & & $-0,0012$ & 0,0186 & 1995 & 0,0046 & 0,0138 \\
\hline 1972 & & 0,0034 & 0,0133 & 1996 & 0,0054 & 0,0094 \\
\hline 1973 & & 0,0035 & 0,0211 & 1997 & 0,0084 & 0,0103 \\
\hline 1974 & & $-0,0092$ & 0,0169 & 1998 & 0,0031 & 0,0162 \\
\hline 1975 & & $-0,0176$ & 0,0270 & 1999 & 0,0056 & 0,0113 \\
\hline 1976 & & 0,0028 & 0,0133 & 2000 & 0,0085 & 0,0062 \\
\hline 1977 & & 0,0004 & 0,0169 & 2001 & 0,0019 & 0,0113 \\
\hline 1978 & & 0,0039 & 0,0148 & 2002 & 0,0042 & 0,0087 \\
\hline 1979 & & 0,0017 & 0,0162 & 2003 & 0,0031 & 0,0077 \\
\hline 1980 & & $-0,0070$ & 0,0211 & 2004 & 0,0079 & 0,0069 \\
\hline 1981 & & $-0,0027$ & 0,0067 & 2005 & 0,0042 & 0,0064 \\
\hline 1982 & & $-0,0075$ & 0,0227 & 2006 & 0,0062 & 0,0064 \\
\hline 1983 & & 0,0024 & 0,0153 & 2007 & 0,0056 & 0,0081 \\
\hline 1984 & & 0,0096 & 0,0147 & 2008 & $-0,0056$ & 0,0095 \\
\hline 1985 & & 0,0050 & 0,0086 & 2009 & $-0,0225$ & 0,0166 \\
\hline 1986 & & 0,0048 & 0,0163 & 2010 & 0,0074 & 0,0140 \\
\hline 1987 & & 0,0037 & 0,0143 & 2011 & 0,0017 & 0,0144 \\
\hline 1988 & & 0,0047 & 0,0117 & 2012 & $-0,0059$ & 0,0105 \\
\hline 1989 & & 0,0038 & 0,0127 & 2013 & $-0,0016$ & 0,0084 \\
\hline 1990 & & 0,0012 & 0,0129 & 2014 & 0,0022 & 0,0105 \\
\hline 1991 & & $-0,0013$ & 0,0132 & 2015 & 0,0044 & 0,0150 \\
\hline 1992 & & 0,0002 & 0,0123 & 2016 & $-0,0007$ & 0,0095 \\
\hline 1993 & & 0,0015 & 0,0109 & 2017 & 0,0013 & 0,0072 \\
\hline Genel Ort. & & 0,0013 & 0,0147 & & & \\
\hline
\end{tabular}

Not. Yazarın hesaplamaları. 
Ek Tablo 2. Ülkelere İlişkin Toplam Faktör Verimliliğindeki Değişim

\begin{tabular}{|c|c|c|c|c|c|c|c|c|c|c|c|}
\hline Ülke & $\begin{array}{r}1970- \\
1974 \\
\end{array}$ & $\begin{array}{r}1975- \\
1979 \\
\end{array}$ & $\begin{array}{r}1980- \\
1984 \\
\end{array}$ & $\begin{array}{r}1985- \\
1989 \\
\end{array}$ & $\begin{array}{r}1990- \\
1994 \\
\end{array}$ & $\begin{array}{r}1995- \\
1999 \\
\end{array}$ & $\begin{array}{r}2000- \\
2004 \\
\end{array}$ & $\begin{array}{r}2005- \\
2009 \\
\end{array}$ & $\begin{array}{r}2010- \\
2014 \\
\end{array}$ & $\begin{array}{r}2015- \\
2017 \\
\end{array}$ & $\begin{array}{r}\text { Genel } \\
\text { Ort. }\end{array}$ \\
\hline İrlanda & 0,0020 & 0,0059 & 0,0004 & 0,0165 & 0,0203 & 0,0191 & 0,0083 & $-0,0063$ & 0,0137 & 0,0304 & 0,0104 \\
\hline İzlanda & 0,0211 & 0,0104 & 0,0051 & 0,0080 & $-0,0038$ & 0,0152 & 0,0115 & 0,0082 & 0,0032 & 0,0161 & 0,0090 \\
\hline Lüksemburg & 0,0067 & $-0,0075$ & 0,0114 & 0,0293 & 0,0122 & 0,0127 & 0,0119 & $-0,0005$ & $-0,0010$ & $-0,0021$ & 0,0077 \\
\hline Norveç & 0,0139 & 0,0118 & 0,0078 & 0,0054 & 0,0155 & 0,0081 & 0,0083 & 0,0010 & $-0,0043$ & $-0,0026$ & 0,0067 \\
\hline Belçika & 0,0211 & 0,0034 & 0,0075 & 0,0079 & 0,0065 & 0,0069 & 0,0076 & 0,0029 & $-0,0003$ & $-0,0010$ & 0,0062 \\
\hline İsveç & 0,0013 & $-0,0010$ & 0,0030 & 0,0039 & 0,0006 & 0,0185 & 0,0112 & 0,0056 & 0,0092 & 0,0094 & 0,0061 \\
\hline Danimarka & $-0,0014$ & 0,0050 & 0,0065 & 0,0043 & 0,0087 & 0,0072 & 0,0072 & $-0,0002$ & 0,0058 & 0,0064 & 0,0050 \\
\hline Hollanda & 0,0110 & 0,0037 & 0,0012 & 0,0066 & 0,0054 & 0,0072 & 0,0066 & 0,0033 & 0,0002 & 0,0064 & 0,0050 \\
\hline İsrail & & & $-0,0042$ & 0,0141 & 0,0077 & 0,0018 & 0,0034 & 0,0069 & 0,0056 & $-0,0031$ & 0,0049 \\
\hline Almanya & $-0,0043$ & 0,0019 & $-0,0020$ & 0,0074 & 0,0077 & 0,0057 & 0,0075 & 0,0018 & 0,0095 & 0,0065 & 0,0043 \\
\hline İngiltere & $-0,0010$ & 0,0023 & 0,0025 & 0,0079 & 0,0020 & 0,0068 & 0,0068 & 0,0025 & 0,0059 & 0,0007 & 0,0039 \\
\hline İsviçre & $-0,0019$ & $-0,0013$ & 0,0023 & 0,0034 & $-0,0008$ & 0,0059 & 0,0068 & 0,0073 & 0,0057 & $-0,0033$ & 027 \\
\hline ABD & 0,0010 & 0,0055 & 0,0001 & 0,0045 & 0,0018 & 0,0011 & $-0,0002$ & 0,0004 & 0,0083 & 0,0045 & 0,0027 \\
\hline Avust & $-0,0018$ & $-0,0004$ & $-0,0007$ & 0,0042 & 0,0041 & 0,0060 & 0,0 & 0,0036 & 0,0006 & 0,0036 & 0,0025 \\
\hline Finlandiya & 0,0000 & $-0,0028$ & 0,0016 & 0,0061 & $-0,0019$ & 0,0141 & 0,0075 & 0,0009 & $-0,0048$ & 0,0009 & 0,0023 \\
\hline Fransa & 0,0024 & $-0,0030$ & 0,0013 & 0,0044 & 0,0036 & 0,0075 & 0,0070 & $-0,0025$ & $-0,0008$ & 0,0000 & 0,0021 \\
\hline & & & & & & & & & & $-0,0014$ & 003 \\
\hline Y. Zelanda & 0,0003 & $-0,0076$ & 0,0023 & $-0,0068$ & 0,0034 & 0,0046 & 0,0050 & $-0,0029$ & $-0,0020$ & 0,0011 & $-0,0003$ \\
\hline Portekiz & $-0,0008$ & $-0,0012$ & $-0,0091$ & 0,0135 & 0,0001 & 0,0051 & $-0,0022$ & $-0,0068$ & $-0,0031$ & $-0,0042$ & $-0,0007$ \\
\hline İtalya & $-0,0056$ & $-0,0024$ & $-0,0025$ & 0,0025 & 0,0038 & 0,0046 & $-0,0008$ & $-0,0136$ & $-0,0005$ & 0,0052 & $-0,0011$ \\
\hline Kanada & $-0,0016$ & $-0,0050$ & $-0,0032$ & $-0,0024$ & $-0,0017$ & 0,0058 & 0,0036 & $-0,0062$ & $-0,0004$ & $-0,0040$ & $-0,0014$ \\
\hline İspanya & $-0,0033$ & $-0,0043$ & 0,0044 & 0,0019 & 0,0000 & 0,0007 & $-0,0023$ & $-0,0104$ & $-0,0082$ & 0,0093 & $-0,0016$ \\
\hline Yunanistan & $-0,0042$ & 0,0001 & $-0,0072$ & $-0,0018$ & $-0,0074$ & 0,0122 & 0,0163 & $-0,0071$ & $-0,0263$ & 0,0034 & $-0,0024$ \\
\hline Türkiye & $-0,0127$ & $-0,0123$ & 0,0058 & $-0,0018$ & $-0,0091$ & $-0,0024$ & 0,0083 & $-0,0130$ & 0,0054 & $-0,0106$ & $-0,0038$ \\
\hline Şili & $-0,0218$ & 0,0084 & $-0,0198$ & 0,0189 & 0,0025 & $-0,0025$ & $-0,0004$ & $-0,0124$ & $-0,0119$ & $-0,0188$ & $-0,0049$ \\
\hline Meksika & $-0,0081$ & $-0,0120$ & $-0,0133$ & $-0,0087$ & 0,0013 & $-0,0005$ & $-0,0032$ & $-0,0176$ & 0,0009 & $-0,0030$ & $-0,0065$ \\
\hline Japonya & $-0,0506$ & $-0,0202$ & $-0,0102$ & $-0,0090$ & $-0,0093$ & $-0,0036$ & 0,0040 & $-0,0067$ & 0,0111 & 0,0049 & $-0,0086$ \\
\hline Kore & 0,0204 & $-0,0221$ & $-0,0176$ & $-0,0169$ & $-0,0292$ & $-0,0210$ & $-0,0044$ & $-0,0058$ & 0,0002 & $-0,0077$ & $-0,0112$ \\
\hline Genel Ort. & $-0,0009$ & $\mathbf{- 0 , 0 0 1 7}$ & $-0,0011$ & 0,0044 & 0,0016 & 0,0054 & 0,0051 & $-0,0024$ & 0,0007 & $\mathbf{0 , 0 0 1 7}$ & 0,0013 \\
\hline
\end{tabular}

Not. Yazarın hesaplamaları. 
Ek Tablo 9. TFE Modeli Sabit Terim Tahminleri

\begin{tabular}{|c|c|c|c|}
\hline \multicolumn{4}{|c|}{$\begin{array}{ll}\text { TFE } & \text { TFE } \\
\text { FRONTIER } & \end{array}$} \\
\hline \multicolumn{4}{|c|}{ FRONTIER } \\
\hline alpha1 & $\begin{array}{l}0,0254 \\
(0,0184)\end{array}$ & alpha17 & $\begin{array}{l}0,122 * * * \\
(0,0124)\end{array}$ \\
\hline alpha2 & $\begin{array}{l}-0,358 * * * \\
(0,0281)\end{array}$ & alpha18 & $\begin{array}{l}-0,193 * * * \\
(0,0188)\end{array}$ \\
\hline alpha3 & $\begin{array}{l}-0,349 * * * \\
(0,0274)\end{array}$ & alpha19 & $\begin{array}{l}0,0202 \\
(0,0532)\end{array}$ \\
\hline alpha4 & $\begin{array}{l}0,0148 \\
(0,00926)\end{array}$ & alpha20 & $\begin{array}{l}0,183 * * * \\
(0,0384)\end{array}$ \\
\hline alpha5 & $\begin{array}{l}-0,0670^{*} \\
(0,0391)\end{array}$ & alpha21 & $\begin{array}{l}-0,552 * * * \\
(0,0307)\end{array}$ \\
\hline alpha6 & $\begin{array}{l}-0,345^{* * *} \\
(0,0348)\end{array}$ & alpha22 & $\begin{array}{l}-0,0540 * * * \\
(0,0178)\end{array}$ \\
\hline alpha7 & $\begin{array}{l}-0,397 * * * \\
(0,0383)\end{array}$ & alpha23 & $\begin{array}{l}-0,0537 * * * \\
(0,0108)\end{array}$ \\
\hline alpha8 & $\begin{array}{l}0,151 * * * \\
(0,0185)\end{array}$ & alpha24 & $\begin{array}{l}-0,358^{* * *} \\
(0,0292)\end{array}$ \\
\hline alpha9 & $\begin{array}{l}0,286 * * * \\
(0,0267)\end{array}$ & alpha25 & $\begin{array}{l}-0,185^{* * *} \\
(0,0244)\end{array}$ \\
\hline alpha10 & $\begin{array}{l}-0,486 * * * \\
(0,0286)\end{array}$ & alpha26 & $\begin{array}{l}0,136 * * * \\
(0,0169)\end{array}$ \\
\hline alpha11 & $\begin{array}{l}0,399 * * \\
(0,155)\end{array}$ & alpha27 & $\begin{array}{l}0,0538 * * * \\
(0,0141)\end{array}$ \\
\hline alpha12 & $\begin{array}{l}-0,121 * * * \\
(0,0461)\end{array}$ & alpha28 & $\begin{array}{l}1,112 * * * \\
(0,0694)\end{array}$ \\
\hline alpha13 & $\begin{array}{l}-0,314 * * * \\
(0,0444)\end{array}$ & & \\
\hline alpha14 & $\begin{array}{l}0,135 * * * \\
(0,0216)\end{array}$ & & \\
\hline alpha15 & $\begin{array}{l}0,442 * * * \\
(0,0413)\end{array}$ & & \\
\hline alpha16 & $\begin{array}{l}-0,180 * \\
(0,106)\end{array}$ & & \\
\hline
\end{tabular}

Not. Yazarın hesaplamaları. 


\section{Kaynakça}

Abramovitz, M. (1956). "Resource and output trends in the United States since 1870". The American Economic Review, 46(2), 5-23.

Aguiar, D., Costa, L., \& Silva, E. (2017). "An attempt to explain differences in economic growth: A stochastic frontier approach". Bulletin of Economic Research, 4, E42-E65.

Ahmadzai, H. (2017). "Crop diversification and technical efficiency in Afghanistan: Stochastic frontier analysis". CREDIT Research Paper, 17(04).

Arcelus, F. J., \& Arocena, P. (2000). "Convergence and productive effciency in fourteen OECD countries: A non-parametric frontier approach". International Journal of Production Economics, 66(2), 105-117.

Archibugil, D. \&Michie, J. (1998). “Technical change, growth snd trade: New departures in institutional economics”. Journal of Economic Surveys, 12(3), 313-332.

Barro, R. J. \& Lee, J. W. (2013). "A new data set of educational attainment in the world, 1950-2010". Journal of Development Economics, 104, 184-198. Web: http://www.barrolee.com/ Updated: 2018.

Battese, G. E., \& Coelli, T. J. (1988). "Prediction of firm-level technical efficiencies with a generalized frontier production function and panel data". Journal of Econometrics, 38(3), 387-399.

Battese, G. E., \& Coelli, T. J. (1992). "Frontier production functions, technical efficiency and panel data: With application to paddy farmers in India". Journal of Productivity Analysis, 3(1), 153169.

Batttese, G. E., \& Coelli, T. J. (1995). "A model for technical inefficiency effects in a stochastic frontier production function for panel data". Empirical Economics, 20(2), 325-332.

Belotti, F., Daidone, S., Ilardi, G., \& Atella, V. (2013). "Stochastic frontier analysis using Stata". The Stata Journal, 13(4), 719-758.

Bocutoğlu, E. (2012). Karşılaştırmalı makro iktisat: Teoriler ve politikalar. Trabzon: Murathan Yayınevi.

Bos, J., Economidou, C., Koetter, M., \& Kolari, J. (2010). "Do all countries grow alike?" Journal of Development Economics, 91(1), 113-127.

Caselli, F. (2005). "Accounting for cross-country income differences". Handbook of Economic Growth, $1,679-741$.

Cohen, D., Leker, L. \& Soto, M. (2014). International educational attainment database. Web: (http://www. parisschoolofeconomics. eu/en/cohen-daniel/international-educational-attainmentdatabase/).

Desli, E., C. Ray, S., \& Kumbhakar, S. (2003). A dynamic stochastic frontier production model with time-varying efficiency". Applied Economics Letters, 10(10), 623-626. 
Du, K. (2017). Translog: Stata module to create new variables for a translog function, statistical software components S458318, Boston College Department of Economics. Link: https://ideas.repec.org/c/boc/bocode/s458318.html

Easterly, W., \& Levine, R. (2001). "What have we learned from a decade of empirical research on growth? It's not factor accumulation: Stylized facts and growth models". The World Bank Economic Review, 15(2), 177-219.

Färe, R., Grosskopf, S., Norris, M., \& Zhongyang, Z. (1994). "Productivity growth, technical progress, and efficiency change in industrialized countries". The American Economic Review, 84, 66-83.

Forstner, H., \& Isaksson, A. (2002). "Productivity, technology, and efficiency: An analysis of the world technology frontier; when memory is infinite". Statistics and Information Networks Branch of UNIDO.

Fuente-Mella, H. d., Vallina-Hernandez, A. M., \& Fuentes-Solís, R. (2020). "Stochastic analysis of the economic growth of OECD countries". Economic Research-Ekonomska Istraživanja, 33(1), 2189-2202.

Golany, B., \& Thore, S. (1997). "The economic and social performance of nations: Efficiency and returns to scale". Socio-Economic Planning Sciences, 31(3), 191-294.

Greene, W. (2005a). "Fixed and random effects in stochastic frontier models". Journal of Productivity Analysis, 23(1), 7-32.

Greene, W. (2005b). "Reconsidering heterogeneity in panel data estimators of the stochastic frontier model". Journal of Econometrics, 126(2). 269-303.

Hagemann, H. (2009). "Solow's 1956 contribution in the context of the Harrod-Domar model". History of Political Economy, 41(1). 67-87.

Hall, R. E., \& Jones, C. I. (1999). "Why do some countries produce so much more output per worker than others?". The Quarterly Journal of Economics, 114(1), 83-116.

Harrod, R. F. (1939). "An essay in dynamic theory". The Economic Journal, 49(193), 14-33.

Harrod, R. F. (1948). Towards a dynamic economics: some recent developments of economic theory and their application to policy. London: MacMillan and Company,

Heshmati, A., \& Rashidghalam, M. (2020). "Estimation of technical change and TFP growth based on observable technology shifters". Journal of Productivity Analysis, 53, 21-36.

Hoover, H. C., \& L. H. Hoover (1912), Georgius Agricola de re metallica: Translated from the Latin edition of 1556, Reprinted 1950. New York: Dover.

Hou, Z., Roseta-Palma, C., \& Ramalho, J. J. (2020). "Directed technological change, energy and more: A modern story". Environment and Development Economics, 25(6). 611-633.

Human Capital in PWT 9.0. (n.d.). [ebook] Penn World Table. Available at: http://www.rug.nl/ggdc/docs/human_capital_in_pwt_90.pdf [Erişim: 10/10/2020]. 
Jondrow, J., Lovell, C. K., Materov, I. S., \& Schmidt, P. (1982). "On the estimation of technical inefficiency in the stochastic frontier production function model". Journal Of Econometrics, 19(23), 233-238.

Jones, C. (2001). İktisadi büyümeye giriş. (Çev: Ateş, Ş. \&Tuncer, İ.). İstanbul: Literatür Yayınc1lık.

Kalirajan, K. P., \& Shand, R. T. (1999). "Frontier production functions and technical efficiency measures". Journal of Economic Surveys, 13(2), 149-172.

Keynes, J. (1936). The general theory of employment, interest and money. Ed: Macmillan London.

Kim, D. S. (1999). A standardization technique to reduce the problem of multicollinearity in polynomial regression analysis.

Link: http://citeseerx.ist.psu.edu/viewdoc/download?doi=10.1.1.573.1999\&rep=rep1\&type $=\mathrm{df}$

Kim, S., Park, D., \& Park, J.-H. (2010). "Productivity growth across the world, 1991-2003". Asian Development Bank Economics Working Paper Series(212).

Koop, G., Osiewalsk1, J., \& Steel, M. F. (2000). "A stochastic frontier analysis of output level and growth in Poland and western economies". Economics of Planning, 33(3), 185-202.

Kök, R. (1991). Endüstriyel verimlilik ve etkinlik-bir uygulama. Yayınlanmamış Doktora Tezi. Atatürk Üniversitesi, Sosyal Bilimler Enstitüsü, Erzurum.

Kök, R., \& Deliktaş, E. (2003). Endüstri İktisadında verimlilik ölçme ve strateji geliştirme teknikleri. İzmir: DEÜ İ̈BF Yayınları, Yayın Karar No:25-8/1.

Kumbhakar, S. C. (1990). "Production frontiers, panel data, and time-varying technical inefficiency". Journal of Econometrics, 46(1-2), 201-211.

Kumbhakar, S. C., \& Heshmati, A. (1995). "Efficiency measurement in Swedish dairy farms: an application of rotating panel data, 1976-88. American Journal of Agricultural Economics, 77(3), 660-674.

Kumbhakar, S. C., Lien, G., \& Hardaker, J. B. (2014). "Technical efficiency in competing panel data models: a study of Norwegian grain farming". Journal of Productivity Analysis, 41(2), 321-337.

Kumbhakar, S., \& Lovell, C. (2000). Stochastic frontier analysis. New York: Cambridge University Press.

Kumbhakar, S. C., Wang, H.-J., \& Horncastle, A. P. (2015). A practitioner's guide to stochastic frontier analysis using Stata. New York: Cambridge University Press.

Kumbhakar, S. C., \& Wang, H. J. (2005). "Estimation of growth convergence using a stochastic production frontier approach". Economics Letters, 88(3), 300-305.

Mahadevan, R. (2004). The Economics of productivity in Asia and Australia. Massachusetts: Edward Elgar Publishing.

Mankiw, N. G., Phelps, E. S., \& Romer, P. M. (1995). "The growth of nations". Brookings Papers on Economic Activity, 1. 275-326.

Marx, K. (2018). Kapital cilt III: Ekonomi politiğin eleştirisi. (Çev. Selik, M. \& Satlıgan, N.), İstanbul: Yordam Kitap. 
Önder, A., Deliktaş, E., \& Lenger, A. (2003). "Efficiency in the manufacturing industry of selected provinces in Turkey: A stochastic frontier analysis". Emerging Markets Finance and Trade, 39(2), 98-113.

Pablo-Romero, M. D. P., \& Gómez-Calero, M. D. L. P. (2013). “A Translog production function for the Spanish provinces: Impact of the human and physical capital in economic growth". Economic Modelling, 32, 77-87.

Pires , J., \& Garcia, F. (2012). "Productivity of nations: A stochastic frontier approach to TFP Decomposition". Economics Research International(Article ID 584869), 1-20.

Psacharopoulos, G. (1994). "Returns to investment in education: A global update". World Development, 22(9), 1325-1343.

Rao, D.S.P. \& Coelli, T.J. (1998). "A cross-country analysis of GDP growth catch-up and convergence in productivity and inequality", Centre for Efficiency and Productivity Analysis (CEPA). Working Paper No. 5/98, University of New England, Australia.

Reyna, O. (2007). Panel data analysis fixed and random effects using Stata (v. 4.2). Princeton University, 9.

Ricardo, D. 1951. On the principles of political economy and taxation, Sraffa, P. (ed.), Cambridge, Cambridge University Press.

Schumpeter, J. (1934). The theory of economic development (trans. R. Opie). Cambridge, MA: Harvard University Press.

Schumpeter, J. (1950). Capitalism, socialism and democracy (3rd edn b.). New York: HarperPerennial.

Smith, A.,1976. The wealth of nations. Chicago: The University of Chicago Press,

Solow, R. M. (1956). "A contribution to the theory of economic growth". The Quarterly Journal of Economics, 70(1), 65-94.

Solow, R. M. (1957). "Technical change and the aggregate production function". Review of Economics and Statistics, 39(3). 312-320.

Sweezy, P. (1970). Kapitalizm nereye gidiyor?. (Çev. Kafaoğlu, A. B). İstanbul: Ağaoğlu Yayınevi.

Şanlı, D. (2016). "Nitelik uyarlanmış beşeri sermaye endeksi 1976-2013". Bulletin of Economic Theory and Analysis, 1(1), 13-49.

Wang, H.-J. (2002), "Heteroscedasticity and non-monotonic efficiency effects of a stochastic

frontier model," Journal of Productivity Analysis, 18, 241-53.

Wang, H.-J., \& Ho, C.-W. (2010). "Estimating fixed-effect panel stochastic frontier models by model transformation". Journal of Econometrics, 157(2), 286-296.

Wooldridge, J. M. (2003). Introductory econometrics-A modern approach. Ohio: Thomson. Mason. 